\title{
The easternmost tropical Pacific. Part I: A climate review
}

\author{
Jorge A. Amador ${ }^{1,2 *}$, E. R. Rivera ${ }^{1,2}$, A. M. Durán-Quesada ${ }^{1,2}$, G. Mora ${ }^{1,2}$, F. Sáenz ${ }^{2}$, \\ B. Calderón ${ }^{2} \&$ N. Mora $^{2}$ \\ 1. Escuela de Física, Universidad de Costa Rica, 11501-2060 San José, Costa Rica; jorge.amador@ucr.ac.cr \\ 2. Centro de Investigaciones Geofísicas, Universidad de Costa Rica, 11501-2060 San José, Costa Rica.
}

Received 17-IV-2015. Corrected 02-VII-2015. Accepted 07-VII-2015.

\begin{abstract}
The tropics are characterized by a variety of atmospheric and oceanic systems dominated by multiscale interaction processes. This is Part I of a two-part review study on climate and climate variability of the Eastern Tropical Pacific (ETP). Here, the mean fields of incoming short wave radiation, surface energy fluxes, sea surface temperature, sea level pressure, salinity, wind patterns at $10 \mathrm{~m}$ height, wind stress curl, precipitation, and evaporation are analyzed and synthetized using available data including that from the last decade. Given the strong interaction between the ETP and Caribbean Sea-Atlantic Ocean, mean field discussions are presented for two different domains, a relatively large domain from $24^{\circ} \mathrm{S}-36^{\circ} \mathrm{N}$ and between $129^{\circ} \mathrm{W}-17^{\circ} \mathrm{W}$, and a smaller domain embedding only the Caribbean Sea and the easternmost part of the ETP. Most results on the climate of these two regions can be used as the base line for climate change studies. Interannual variability of tropical cyclones is also investigated over the domain of the latter two basins in the smaller domain. The study is complemented with a short review of some low frequency modes, such as, El Niño-Southern Oscillation, the Pacific Decadal Oscillation, and the Atlantic Multi-decadal Oscillation. Such low-frequency modes are known to modulate regional systems, including tropical cyclone frequency. Rev. Biol. Trop. 64 (Suppl. 1): S1-S22. Epub 2016 February 01.
\end{abstract}

Key words: Cocos Island, Isla del Coco, Eastern Tropical Pacific, Caribbean Sea, climate, tropical cyclones, low frequency modes, shallow meridional circulation.

The tropical regions are characterized by a wide range of atmospheric motions dominated by non-linear interactions in different time and space scales. Many local, regional and international experiments have provided data to study these interactions and the mechanisms behind the observed ocean-atmosphere structure and modes of variability. The Intra Americas Sea (IAS) is a region comprising the Gulf of Mexico (GM), the Caribbean Sea (CS), the Eastern Tropical Pacific (ETP), and embedded continental areas. The IAS is a major global nest of atmospheric and oceanic features that has been frequently the area of interest for several studies. Amador, Alfaro, Lizano, \& Magaña (2006), made a short review of experiments and campaigns in the IAS, up to the middle of the last decade. Amador et al. (2006) included a review of the climate and seasonal behavior of the atmosphere and upper-ocean in this region. The above work was carried out in the framework of an international project funded by the Inter-American Institute for Global Change Research (IAI) on Comparative Studies and Assessment of the Impacts of Global Change on the Pelagic and Near-Shore Ecosystems of the North and South Pacific Eastern Boundary Currents (IAI-CRN062). Some of the scientific contributions of IAI-CRN062 were published in a special issue of Progress in Oceanography (A Review of Eastern Tropical Pacific Oceanography, Volume 69, Issues 2-4, Pages 91-398, May-June 2006). Before the publication of this issue, detailed analyses of the annual cycle of 
the lower atmosphere and the underlying ocean in the tropics, had been reported by Hastenrath \& Lamb (1978); Hastenrath (1991); Horel (1982); Sadler, Lander, Hori \& Oda (1987a; 1987b); Taylor (1973); Wyrtki (1965a; 1965b; 1966; 1967); Wyrtki \& Meyers (1975a; 1975b), among others.

The present work (Part I of the study, and a companion work, Part II), aim at extending the contribution of Amador et al. (2006), by using new atmospheric and oceanic information for a longer period of observations with higher quality controlled climatic data. The data comes from international projects and regional experiments including atmospheric and oceanic information from the last decade. Periods used span, in most cases, from the 1980's to 2010's (see Table 1). The integral objectives of this work and its companion are in accordance with the framework of the project "Consejo Nacional de Rectores (CONARE): Interacciones océanoatmósfera y la biodiversidad marina de la Isla del Coco, Costa Rica", in order for oceanographers, marine biologists, ecologists, and other ocean and atmospheric scientists, to have a guiding base for most ocean-atmospheric interaction processes affecting, among others, the waters of the Cocos Island, a World Heritage site of Costa Rica. Cocos Island is one of the highest concentration hotspots of biodiversity and endemics per unit area of the Indo-Pacific (Allen, 2008). Moreover, the World Heritage Convention remarks that this island is the only one with tropical rainforest in the ETP (Reyes, $\&$ Vogel, 1981). Weather and climate are fundamental to understand the biological richness of the island and its surrounding waters. The island owes its biodiversity mainly to regional precipitation and the interaction of the island's myriads with oceanic currents (Guzmán, \& Cortés, 2001).

This work is a climate review of ETP main low-level atmospheric and near surface oceanic structure. Data and procedures used in this research are described in the next section. Section 2 presents the mean state of the ETP lower troposphere, especially the behavior of variables near the sea surface. Solar radiation, surface energy fluxes, sea surface temperature (SST), sea level pressure and salinity mean fields are first presented. The section continues with an overview of $10 \mathrm{~m}$ height wind fields and the wind stress curl. Mean annual precipitation and evaporation are then reviewed. Known

TABLE 1

Variables, periods and sources of data used in this study

\begin{tabular}{|c|c|c|}
\hline Variable(s) & Period & Source \\
\hline $\begin{array}{l}\text { Shortwave radiation, net } \\
\text { heat flux }\end{array}$ & 1984-2009 & $\begin{array}{l}\text { International Satellite Cloud Climatology Project (Y-C. Zhang, Rossow, Lacis, } \\
\text { Oinas, \& Mishchenko, 2004): http://isccp.giss.nasa.gov/projects/flux.html }\end{array}$ \\
\hline $\begin{array}{l}\text { Sensible heat flux, latent } \\
\text { heat flux, sea surface } \\
\text { temperature, evaporation }\end{array}$ & $1980-2012$ & $\begin{array}{l}\text { The Objectively Analyzed Air-sea Fluxes (OAFlux) project (Yu et al., 2008): } \\
\text { http://oaflux.whoi.edu/ }\end{array}$ \\
\hline Sea surface temperature & $1982-2012$ & $\begin{array}{l}\text { NOAA Optimal Interpolation SST version } 2 \text { (OISSTv2, Reynolds et al., 2007): } \\
\text { http://www.esrl.noaa.gov/psd/data/gridded/data.noaa.oisst.v2.html }\end{array}$ \\
\hline Mean sea level pressure & $1980-2012$ & $\begin{array}{l}\text { ERA-interim reanalysis (Dee et al., 2011): http://www.ecmwf.int/en/research/ } \\
\text { climate-reanalysis/era-interim }\end{array}$ \\
\hline Salinity at $5 \mathrm{~m}$ depth & $1980-2008$ & $\begin{array}{l}\text { Simple Ocean Data Assimilation (SODA, Carton, \& Giese, 2008): } \\
\text { http://iridl.ldeo.columbia.edu/ }\end{array}$ \\
\hline Ocean surface wind vectors & $1990-2011$ & $\begin{array}{l}\text { Cross-Calibrated Multi-Platform (CCMP) Ocean Surface Vector Analysis } \\
\text { (Atlas et al., 2011): https://podaac.jpl.nasa.gov/Cross-Calibrated_Multi- } \\
\text { Platform_OceanSurfaceWindVectorAnalyses }\end{array}$ \\
\hline Precipitation & $1998-2013$ & $\begin{array}{l}\text { Tropical Rainfall Measuring Mission (TRMM) version } 7 \text { (3B42, Huffman et } \\
\text { al., 2007): http://iridl.ldeo.columbia.edu/ }\end{array}$ \\
\hline
\end{tabular}


physical mechanisms associated with the atmosphere or ocean structure are invoked, when appropriate. Most atmospheric systems impacting the IAS also vigorously affect the ETP therefore, a review of the systems in the latter region must include those of the IAS. A sidebar is appended after section 2 to present the shallow meridional circulation associated with the Hadley cell as a significant feature relevant to the ETP climate. Section 3 gives an overview of interannual variability of tropical cyclone frequency, for both, the Caribbean basin and the ETP. Low atmospheric frequency modes affecting the ETP, such as, El Niño-Southern Oscillation (ENSO), the Pacific Decadal Oscillation (PDO), and the Atlantic Multi-decadal Oscillation (AMO) are briefly discussed in section 4. In regard to the importance of the study of these low-frequency modes in the ETP, the effect of interannual signals on the Cocos Island has been well documented (Guzmán, \& Cortés, 1992). This section stresses the interactions of these low-frequency modes with the annual scales, their modulation of precipitation and wind, as well as, their relationship with tropical cyclone interannual frequency. Section 5 presents the summary and conclusions of Part I. Part II (Amador et al., 2015) presents an account of major climate seasonal or monthly variability modes. Seasonal observed changes of atmospheric and ocean parameters, precipitation and evaporation, and some intraseasonal modes of variability (e.g., MaddenJulian Oscillation, MJO) are discussed. At the end of Part II, a short review of monthly tropical cyclones and their space frequency over the ETP and Caribbean are also presented. A sidebar is also appended in Part II to discuss the presence of atmospheric rivers in the ETP region. Part I and Part II are expected to be the reference and basis for other works in this special supplement of the Journal.

\section{Data and procedures}

The first area selected for the spatial plots of the atmospheric and oceanic variables used in this work is, for convenience of comparison, an extension of the Central America domain as defined in the Coordinated Regional Climate Downscaling Experiment (CORDEX) framework (http://wcrp-cordex.ipsl.jussieu.fr/). The region extends approximately from $24^{\circ} \mathrm{S}-36^{\circ}$ $\mathrm{N}$ and between $129^{\circ} \mathrm{W}-17^{\circ} \mathrm{W}$. When information and resolution allow, patterns of atmospheric and ocean variables are also shown for the smaller area $0^{\circ}-20^{\circ} \mathrm{N}-65^{\circ}-95^{\circ} \mathrm{W}$. The former area gives the large scale conditions of atmosphere and ocean and provides an opportunity for climate modeling studies (e.g., CORDEX), while the latter offers a closer view of the details of these parameters in the context of the Isla del Coco project. Table 1 lists the variables, the periods and data sources used in this study. Figure 1 shows the region of analysis (with the smaller subdomain), including country boundaries, topography and important geographical markers that are referenced in the text (Cocos Island, Isthmus of Tehuantepec, among others).

Ocean-atmosphere flux information from the Objectively Analyzed Air-sea Fluxes (OAFlux) Project (Yu, Jin, \& Weller, 2008) is used. OAFlux estimates are based on surface meteorological fields derived from satellite remote sensing (e.g., Special Sensor Microwave Imager, SSM/I), column water vapor retrievals and reanalysis outputs produced from National Center for Environmental Prediction (NCEP) and European Centre for Medium Range Weather Forecasts (ECMWF) models using a Center for Oceanic Awareness Research \& Education (COARE) bulk algorithm. Wind speed used by OAFlux comes from SSM/I, AMSR-E (Advanced Microwave Scanning Radiometer - Earth Observing System) and the Quick Scatterometer (QuikSCAT). Humidity information from SSM/I 10m humidity was adjusted to $2 \mathrm{~m}$ humidity following the COARE3.0 flux algorithm and then assimilated in OAFlux. SST data comes from the National Atmospheric and Atmospheric Administration (NOAA) Optimum Interpolation (OI) $0.25^{\circ}$ daily SST analysis (Reynolds et al., 2007). The combination of the satellite retrievals and reanalysis data was performed under the basis 


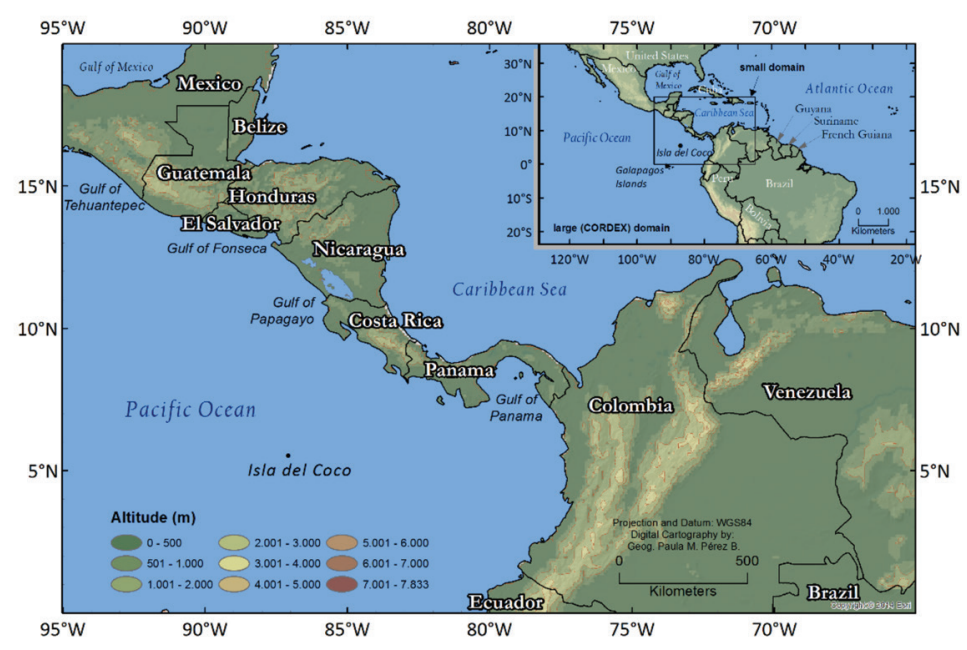

Fig. 1. Region of analysis for the large (Central America CORDEX) domain (http://wcrp-cordex.ipsl.jussieu.fr/), with the smaller subdomain comprising the Caribbean Sea and the Easternmost Tropical Pacific, including country boundaries, topography and important geographical markers that are referenced in the text (Isthmus of Tehuantepec, Gulf of Fonseca, among others). Cocos Island approximate location at $5^{\circ} 31^{\prime} 60^{\prime} \mathrm{N}, 87^{\circ} 04^{\prime} 00^{\prime} \mathrm{W}$.

of the Gauss-Markov theorem. In synthesis, the OAFlux products herein used are latent and sensible heat fluxes, net surface energy flux and evaporation. SST was also retrieved from the OISST (NOAA Optimum Interpolation Sea Surface Temperature Analysis) product (Reynolds, Rayner, Smith, Stokes \& Wang, 2002). The selection of the dataset was based on the spatial resolution of the data $\left(0.25^{\circ}\right.$ grid resolution of global coverage). An optimum interpolation of Pathfinder AVHRR (Advanced Very High Resolution Radiometer) data yields the OISST product. The interpolation includes error reduction due to presence of ice and clouds, enhanced temporal smoothing techniques as well as satellite bias correction from in situ data.

Precipitation from the Tropical Rainfall Measuring Mission (TRMM) version 7 (3B42, Huffman et al., 2007) was used. Other data sets such as the Global Precipitation Climatology Project (GPCP) Version-2 (Adler et al., 2003) do not have the required resolution for detailed analysis as needed here. Salinity at $5 \mathrm{~m}$ depth data from the Simple Ocean Data Assimilation (SODA) dataset (Carton, \& Giese, 2008) was retrieved from the http://iridl.ldeo.columbia. edu site. The SODA dataset has an average resolution of $1^{\circ} \times 1^{\circ}$ and was assimilated by the Parallel Ocean Program model using the atmospheric forcing from a second generation ECMWF reanalysis, known as ERA-40 Reanalysis (Uppala et al., 2005). The set also accounts for observations that include available hydrographic profile data, moored temperature, salinity time series, surface temperature and salinity observations of various types, ocean station data and infrared satellite SST data.

Surface pressure data from the public available global ERA-Interim Reanalysis (Dee et al., 2011) monthly fields were used. The ERA-Interim set was selected as it covers the required analysis period here and its resolution is suitable for the purposes of this work. The reanalysis is based on a sequential assimilation scheme that incorporates available observations with information from a forecast model. The method considers atmospheric and surface analysis and the reanalysis is produced with the ECMWF Integrated Forecast System. The use of observations in the assimilation system was carried out under a strict selection and control procedure to ensure the quality of the reanalysis. For more details on the assimilation 
process, the available variables and bias information see Dee et al. (2011).

Satellite wind data from the Cross-Calibrated Multi-Platform (CCMP) Ocean Surface Vector Analysis, were used to generate seasonal wind patterns in the tropical Americas. This dataset provides long time series of ocean surface analysis, starting in July 1987 and ending in 2011. For consistency purposes with other available variable periods, a temporal period of 22 years was used (from 1990 through 2011), whereas the spatial resolution is $0.25^{\circ} \times 0.25^{\circ}$. The wind stress curl was computed from the above wind data set using the wind drag coefficient given in Holton (2004).

Time series of tropical cyclone frequency and intensity for the ETP and Caribbean basins were constructed from records from the Hurricane Data second generation (HURDAT2) database provided by the National Hurricane Center (NHC). In addition, the multivariate ENSO index (MEI) (Wolter, \& Timlin, 1998), as well as the PDO index (Mantua, Hare, Zhang, Wallace, \& Francis, 1997) and the AMO index (Enfield, Mestas-Núñez, \& Trimble, 2001) were used to analyze the low frequency variability of tropical cyclone activity in the above two oceanic regions.

\section{The mean state of the lower atmosphere}

\subsection{Radiation and surface energy fluxes}

Incoming shortwave radiation is maximum in tropical regions, being a relevant source for convective activity and system development. Values greater than $200 \mathrm{Wm}^{-2}$ prevail in the IAS, with some regions exceeding these values in the ETP (Fig. 2). Note in this and most of the following figures, a black dot in the ETP, showing the approximate location of the Cocos Island at $5^{\circ} 31^{\prime} 60^{\prime \prime} \mathrm{N}-87^{\circ} 4{ }^{\prime} 0$ " W. Near the Pacific coast of Central America, extending to southwestern Mexico, a maximum of more than $220 \mathrm{Wm}^{-2}$ is observed. Southeast of this region, a minimum associated with the northern edge of the Pacific cold tongue and near the Panama Bight is present. Also the region associated with the Intertropical Convergence Zone (ITCZ) shows minimum values. Note the values of incoming radiation in excess of $240 \mathrm{Wm}^{-2}$ over the central Caribbean.

Net surface energy flux, a balance between net downward shortwave radiation, net upward longwave radiation, latent, and sensible heat fluxes, is good to depict flux variability on synoptic, seasonal, and interannual timescales (Yu, Jin, \& Weller, 2007). Its distribution in the ETP region is mostly positive displaying two maxima (Fig. 3). On average, the region west of Costa Rica Pacific coast presents values close to $100 \mathrm{Wm}^{-2}$. This is a secondary maximum when compared to the $150 \mathrm{Wm}^{-2}$ belt

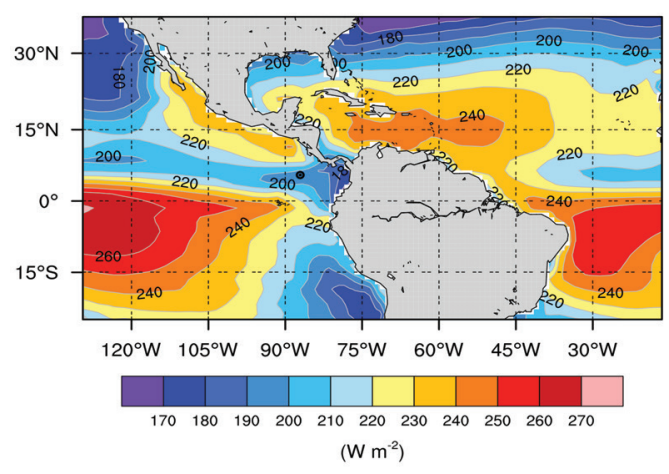

Fig. 2. Incoming shortwave radiation $\left(\mathrm{Wm}^{-2}\right)$. See Table 1 for details on data and data sources. Black dot shows the Cocos Island approximate location at $5^{\circ} 31^{\prime} 60^{\prime \prime} \mathrm{N}, 87^{\circ}$ 04 '00"W.

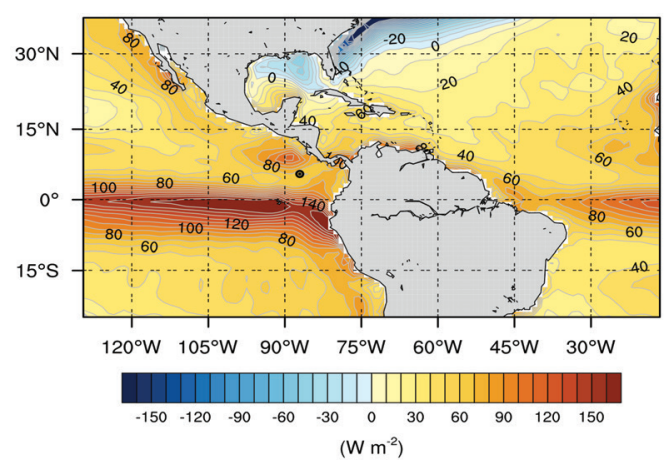

Fig. 3. Net surface energy flux $\left(\mathrm{Wm}^{-2}\right)$. See text for its definition, and Table 1 for details on data and data sources. Black dot shows the Cocos Island approximate location at

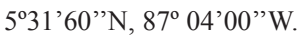


over the equator, enclosing a region with net surface energy flux over $200 \mathrm{Wm}^{-2}$ on average, west of Galapagos. The belt of maximum net surface energy flux corresponds to a region well known to receive a large amount of incoming solar radiation (Fig. 2). Negative values are observed following the Gulf Stream. Note the improvement in the details of this pattern when compared with Figure 11 of Amador et al. (2006). The distribution of this variable is relevant for regional climate as a reservoir of energy for potential moisture availability for convective and transport processes.

The sensible heat flux $\left(\mathrm{Wm}^{-2}\right)$, is a quantity related to the temperature of the system. Over the ocean surface, this term is a function of the SST. Figure 4 shows the regions where these fluxes are relatively high and energy from the ocean surface can be transferred, by conduction and convection, to the atmosphere under certain ocean-atmosphere conditions. Relevant sensible heat flux gradients are observed in both marine waters of Costa Rica, one of them associated with the Costa Rica Dome (Umatani, \& Yamagata, 1991; Fiedler, 2002, Alfaro, \& Cortés, 2012) in the Pacific. Some of the largest fluxes are located along the main oceanic currents (e.g., east of Florida in the United States). Note also the low values of sensible heat flux associated with the equatorial SSTs over the Pacific, in the so called "cold tongue".

The latent heat flux $\left(\mathrm{Wm}^{-2}\right)$ is the energy transfer when liquid water evaporates to the gas phase. In the atmosphere, it is the energy released when the water vapor condenses. Regions of high latent heat flux (Fig. 5) are observed in most of the Caribbean, in clear contrast to the Pacific Ocean pattern. High latent heat fluxes are largely connected with regions of potential evaporation. As reported by Durán-Quesada, Gimeno, Amador \& Nieto (2010), the Caribbean is a very important region for evaporation and moisture transport. Note that in general, latent heat flux is at least one order of magnitude larger than sensible heat flux (see Fig. 4 and 5). Regions where latent heat flux is relatively large, as CS, are prone to generate convective activity, although large latent heat flux is a necessary but not sufficient condition for convection.

\subsection{Sea surface temperature, sea level pressure and salinity}

The SST distribution (Fig. 6A), using the OISST data, is characterized by warm waters enclosing the ETP region southwest of the Isthmus of Tehuantepec and west of Costa Rica. SSTs in excess of $28^{\circ} \mathrm{C}$, are observed just east of Central America over the Caribbean. Warm waters also extend on average to the tropical Atlantic, with the warmest waters following the Atlantic coastline of South America. The

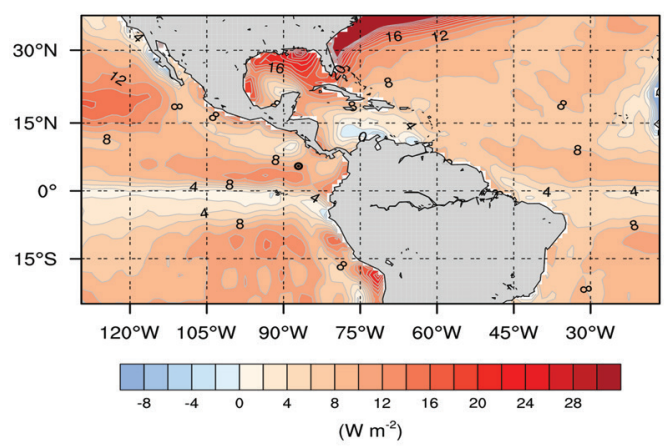

Fig. 4. Sensible heat flux $\left(\mathrm{Wm}^{-2}\right)$. See text for its definition, and Table 1 for details on data and data sources. Black dot shows the Cocos Island approximate location at 5'31'60"N, 8704'00'”W.

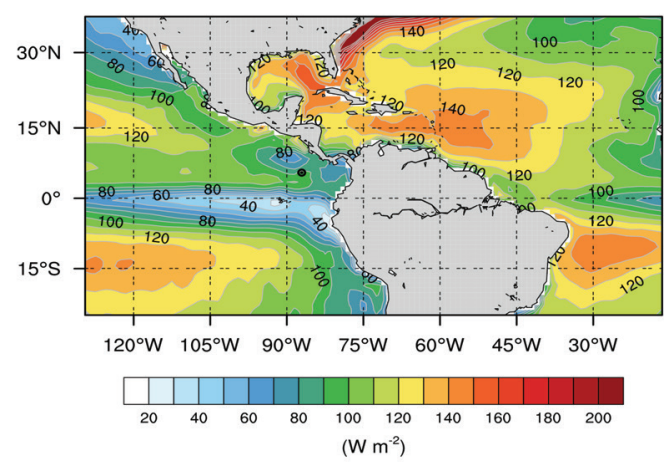

Fig. 5. Latent heat flux $\left(\mathrm{Wm}^{-}{ }^{2}\right)$. See text for its definition, and Table 1 for details on data and data sources. Black dot shows the Cocos Island approximate location at $5^{\circ} 31^{\prime} 60^{\prime \prime} \mathrm{N}, 87^{\circ} 04^{\prime} 00^{\prime \prime} \mathrm{W}$. 

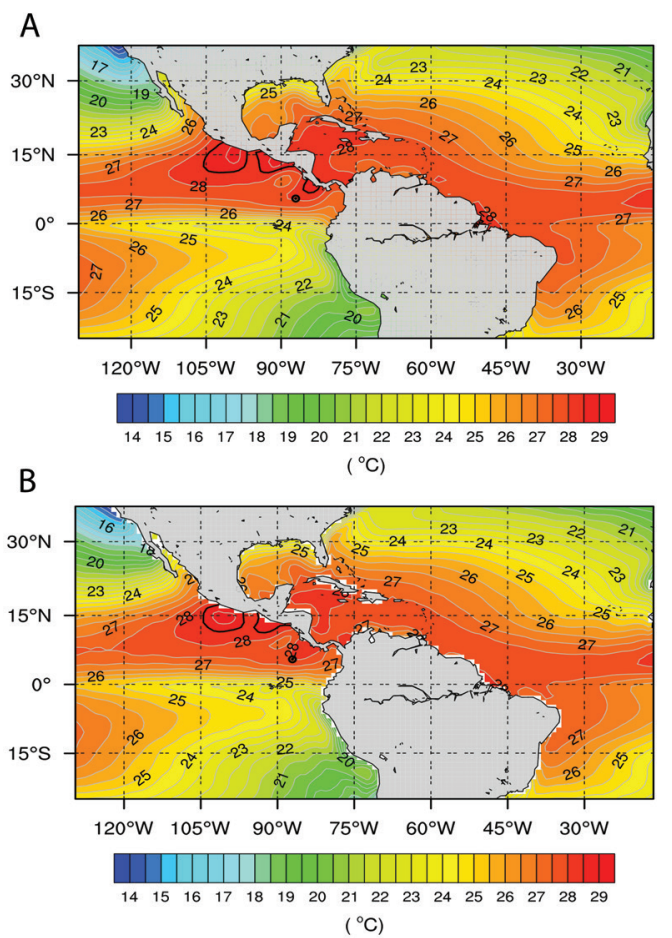

Fig. 6. SST $\left({ }^{\circ} \mathrm{C}\right)$ using a) OISSTv2 and b) OAFlux. See Table 1 for details on data and data sources. Black line denotes the $28.5^{\circ} \mathrm{C}$ isotherm. Black dot shows the Cocos Island approximate location at $5^{\circ} 31^{\prime} 60^{\prime \prime} \mathrm{N}, 87^{\circ} 04^{\prime} 00^{\prime \prime} \mathrm{W}$.

observed SST structure of warm waters, on both sides of the continental area, were named by Wang \& Enfield $(2001 ; 2003)$ as the Western Hemisphere Warm Pool (WHWP), despite the fact that the SST structure on either sides of the continental area evolve independently. The WHWP is an important region for convective activity, tropical storm generation, and the home of strong low-level currents (see further details in Part II). Note the differences between Figs. 6A and 6B, in regard to SST distribution and strength (e.g., near the Pacific coast of Costa Rica and the Pacific cold tongue). Figure 6B was calculated using OAFlux data. These differences could be attributed to differences in input data and algorithms used during processing. The solid black lines in both, Fig. 6A and $6 \mathrm{~B}$ denote the isotherm of $28.5^{\circ} \mathrm{C}$, often used to define the WHWP areas. The seasonal distribution of the SST, including monthly differences between OI and OAFlux data, and the development of the components of the warm pools in both basins are discussed in Part II.

The mean sea level pressure field (Fig. 7) is characterized by the presence of the semipermanent subtropical high pressure systems: the Pacific and Azores anticyclones in the northern hemisphere. Relative low pressure is observed over the southwestern Caribbean and ETP, mostly enclosing southern Central America. This region of low pressure in the ETP is associated with the ITCZ, a belt where trades from the Southern Hemisphere (SH) and Northern Hemisphere (NH) meet. The pressure gradient between mid-latitude and tropics is of great importance in terms of the circulation and modulation of the wind fields.

In the study of air-sea interaction processes, salinity often arises as an important variable to look at; it can provide insightful information on evaporation and precipitation processes. Even small changes in salinity can have important effects on the ocean circulation and water cycle. In the analysis domain, the salinity field at $5 \mathrm{~m}$ depth (Fig. 8) presents a pattern where near-surface waters are more saline in the CS than those of the Pacific. The annual mean distribution of salinity corresponds well with the mean position of the ITCZ, where precipitation is maximum, just northward the Equator. Over the ETP, the ITCZ associated rainfall can be in the order of 3000-3500 mm per year (see

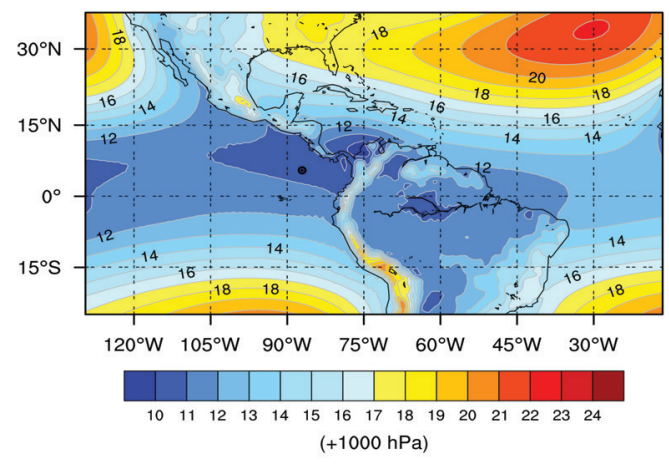

Fig. 7. Mean Sea Level Pressure (hPa). See Table 1 for details on data and data sources. Black dot shows the Cocos Island approximate location at $5^{\circ} 31^{\prime} 60^{\prime \prime} \mathrm{N}, 87^{\circ} 04^{\prime} 00^{\prime}$ W. 


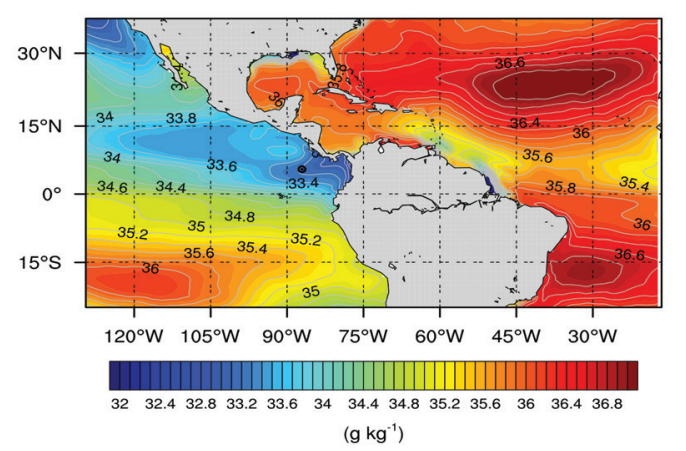

Fig. 8. Salinity $\left(\mathrm{g} \mathrm{kg}^{-1}\right)$ at $5 \mathrm{~m}$ depth. See Table 1 for details on data and data sources. Black dot shows the Cocos Island approximate location at $5^{\circ} 31^{\prime} 60^{\prime \prime} \mathrm{N}, 87^{\circ} 04^{\prime} 00^{\prime \prime} \mathrm{W}$.

Fig. 7 of Amador et al., 2006 and section 2.5 below), so less salinity would be expected in that region. Note also the lower values of salinity in the waters west off Colombia, and Central America; areas linked to regions of intense rainfall (e.g., Poveda, \& Mesa, 2000), and as a consequence of this, to high river discharges. Results from the AQUARIUS satellite mission (see, Lagerloef et al., 2012 for an explanation of the mission) indicate that monthly data averaged between 2012 and 2014, salinity values for the Bengal Bay are larger by approximately 2 Practical Salinity Units (psu) compared with those for the region west off Colombia. However, between February and May salinity in the Bengal Bay drops 1psu compared to salinity west of Colombia. In the tropics, precipitation, evaporation and runoff are the drivers of salinity variations. The similarity of the salinity minimum values between the region west of Colombia and the Bengal Bay is remarkable, however, contrary to the Bengal Bay, the region west off Colombia is not directly affected by the most intense monsoon on Earth.

\subsection{Wind patterns}

Warmer tropics and relatively cold mid and high latitudes generate a meridional pressure gradient that accelerates the surface air masses toward low latitudes. As the air is moving from north to south in the NH, the Earth's rotation results in a deviation the wind motion to its right (Coriolis force). In the $\mathrm{SH}$, the air moves from south to north and the deviation is to the left. The large scale pattern of $10 \mathrm{~m}$ height winds is observed in Fig. 9A. Trades are observed as northeasterly and southeasterly winds in the $\mathrm{NH}$ and $\mathrm{SH}$, respectively. Trade winds prevail in almost all tropical regions. When they cross the Equator, they turn to the opposite direction obeying Coriolis (see the region west of Colombia in Fig. 9A). Of relevance to the region is the wind maximum observed over the Caribbean basin, the Caribbean Low-Level Jet or CLLJ, (Amador 1998, 2008; Whyte, Taylor, Stephenson, \& Campbell, 2008). This system brings abundant moisture (Durán-Quesada et al., 2010) and modulates precipitation over almost all the IAS (Cook \& Vizy, 2010). A more detailed description and properties of the CLLJ is given in Part II. Fig. $9 \mathrm{~B}$ shows the annual mean wind pattern over
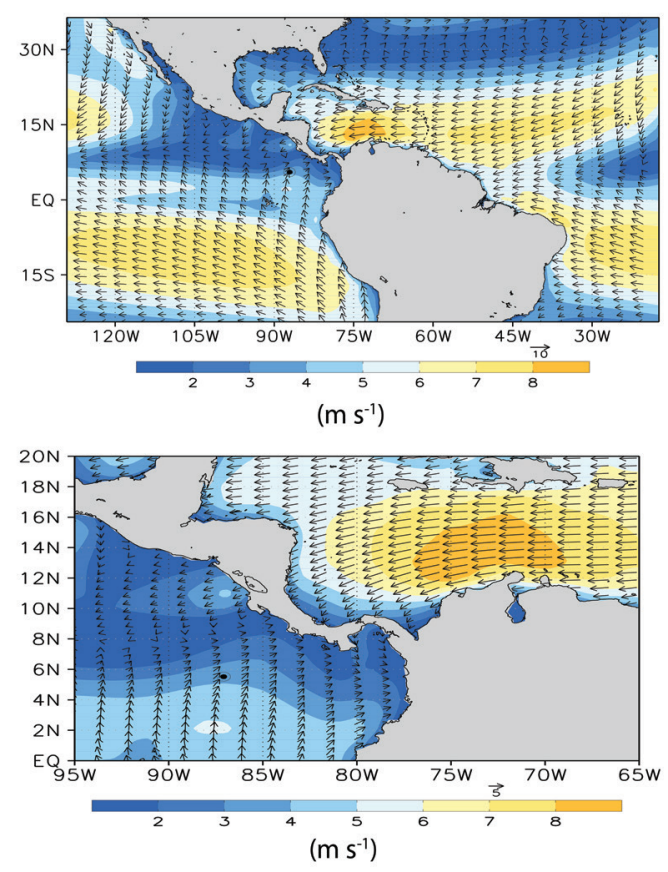

Fig. 9. Annual mean wind $\left(\mathrm{m} \mathrm{s}^{-1}\right)$ patterns over a) the Central America CORDEX region (see text for definition) and $b$ ) the easternmost ETP and Caribbean region. See Table 1 for details on data and data sources. Black dot shows the Cocos Island approximate location at

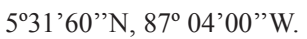


the easternmost ETP and Caribbean region. Note the strength of the trades associated with the mean CLLJ in the central Caribbean. Over the Pacific waters just off Papagayo, winds are as strong as $5 \mathrm{~ms}^{-1}$ on average. This type of wind structure, known to be linked with transisthmic jets and the Costa Rica Dome in the ETP, will be discussed in Part II.

In the central ETP, the ITCZ is located where trades meet. Intense convection develops in that region of low-pressure, as a result of local evaporation and the equatorward moisture transport provided by the wind system. For continuity, ascending motion occurs near the Equator, air masses travel poleward at higher levels to complete the meridional circulation pattern known as the Hadley cell. Sidebar 1 discusses a notable feature in this regime, the shallow meridional circulation in the Hadley cell (see Sidebar 1 for a schematic definition and relevant scientific references).

\subsection{Wind stress curl}

The wind stress curl is the result of space variations in the force exerted by the wind on the ocean surface. It is associated with regions of upward-downward oceanic motion depending on its sign. In the $\mathrm{NH}$, when the wind stress curl is positive (negative) there is ocean upward (downward) motion or upwelling (down-welling). Chelton et al. (2001) have presented evidence in the ETP of coupling between surface wind stress and SST, using QuikSCAT data for a period of three months in 1999. Figure 10 shows the wind stress curl distribution for the extended region used here. North of Venezuela and Colombia, and east of Panama and Costa Rica in the Caribbean Sea, upwelling (positive values of the curl, in red in Fig. 10) is consistent with the equatorward near-surface horizontal wind shear of the CLLJ (Fig. 9A, B) and the relative low values of SST in that region (Fig. 6A, B). This type of dipole structure in the wind stress curl can also be observed, but with less detail, near the Gulf of Papagayo in Costa Rica and the Isthmus of Tehuantepec in southwestern Mexico, where gap jets develop during different seasons. The monthly behavior of this quantity is treated in more detail in Part II.

\subsection{Precipitation and evaporation}

Annual mean precipitation (Fig. 11) clearly shows a contrasting regime between the CS and the ETP. The latter region is featured by a prominent maximum of precipitation associated with the mean position of the ITCZ near $8-9^{\circ} \mathrm{N}$. More than $3500 \mathrm{~mm}$ fall on average in the ITCZ core, an amount consistent with the values reported for a different data set (da Silva, Young, \& Levitus, 1994) by Amador et al. (2006). The Caribbean, in contrast, does not

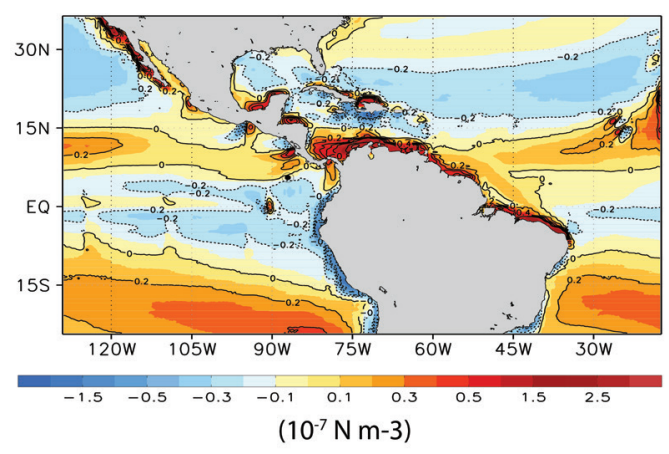

Fig. 10. Wind stress curl $\left(10^{-7} \mathrm{~N} \mathrm{~m}^{-3}\right)$. See Table 1 for details on data and data sources. Black dot with circle shows the Cocos Island approximate location at $5^{\circ} 31^{\prime} 60^{\prime \prime} \mathrm{N}, 87^{\circ} 04^{\prime} 00^{\prime \prime} \mathrm{W}$.

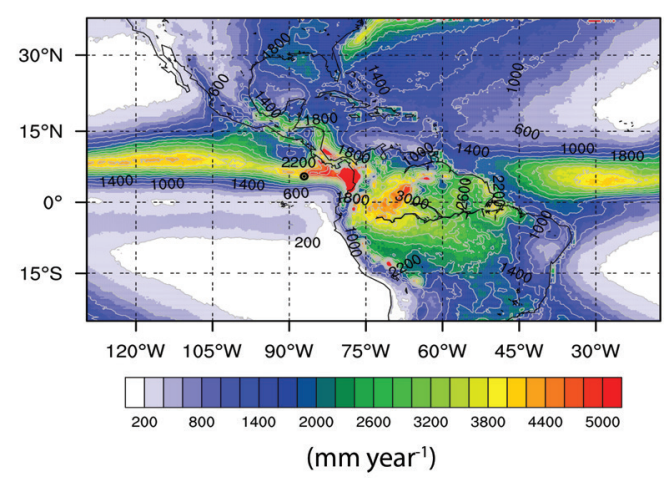

Fig. 11. Precipitation $\left(\mathrm{mm}\right.$ year $\left.{ }^{-1}\right)$. See Table 1 for details on data and data sources. Black dot shows the Cocos Island approximate location at $5^{\circ} 31^{\prime} 60^{\prime \prime} \mathrm{N}, 87^{\circ} 04^{\prime} 00^{\prime \prime} \mathrm{W}$. 


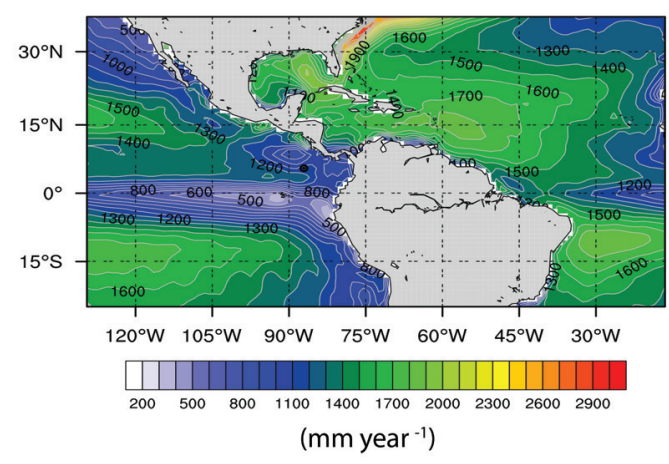

Fig. 12. Evaporation $\left(\mathrm{mm}\right.$ year $\left.{ }^{-1}\right)$. See Table 1 for details on data and data sources. Black dot shows the Cocos Island approximate location at $5^{\circ} 31^{\prime} 60^{\prime \prime} \mathrm{N}, 87^{\circ} 04^{\prime} 00^{\prime \prime} \mathrm{W}$.

show this maximum, instead a region of minimum precipitation is observed. As will be discussed in Part II, the precipitation pattern over the Caribbean and the Pacific coast of Central America, can partially be explained by the presence of the CLLJ (see also, Amador, 1998; 2008) acting as a conveyor belt for moisture transport (Durán-Quesada et al., 2010). Other regions showing large amounts of annual mean precipitation are the Panama Bight, the Chocó (Colombia) and northwestern Costa Rica. The presence of low-level jets in these regions partially explain the annual precipitation maxima observed in Fig. 11 (see also Part II).

Evaporation (Fig. 12) is larger for the CS, the GM and Tropical Atlantic, regions where the latent heat flux is large on average (see Fig. 5). A minimum in evaporation is observed over the equatorial Pacific, under the belt characterized by a maximum of net surface energy flux. The differences in evaporation between the Caribbean and the ETP resemble quite well those differences observed in salinity (Fig. 8). The regions where evaporation is large, salinity is also large. Evaporation near the location of the Costa Rica Dome and in the Panama Bight region presents relative minimum values, although net surface energy flux is positive (see Fig. 3). The patterns of annual mean precipitation and evaporation near the average position of the ITCZ show that precipitation is much greater than evaporation. This structure is indicative of the role played by the trades of both hemispheres in the meridional transport of moisture.

\section{Sidebar 1: Shallow meridional circulation in the Hadley cell- G. Mora}

The winter and summer hemisphere Hadley cells consist of convergent flow toward the ITCZ near the surface, ascending motion close to the Equator, divergent flow at upper tropospheric levels, and descending motion in the subtropics. Embedded in this cell, Zhang, McGauley \& Bond (2004) presented evidence of a shallow meridional circulation (SMC) in the Eastern Pacific, with cross-equatorial return flow just above the top of the frictional boundary layer. This SMC is observed as southerly flow at the lowest levels, with a shallow return northerly flow between 1 and $5 \mathrm{~km}$. In contrast, the well-known northerly flow of the deep Hadley circulation is found between 10 and $12 \mathrm{~km}$ (Fig. S1 is a schematic view of the $\mathrm{SMC}$ ). Wang, Xie, Wang \& $\mathrm{Xu}$ (2005) found that the SMC is strongest between $85^{\circ} \mathrm{W}$ and $125^{\circ} \mathrm{W}$, with a tendency to become deeper toward the west, which seems to be correlated with the increase of the inversion height toward the west (Neiburger, Johnson, \& Chien, 1961; von Ficker, 1936). Its meridional extent also varies in the zonal direction. For example, east of $105^{\circ} \mathrm{W}$ the SMC is confined between $5^{\circ} \mathrm{S}$ and the northern ITCZ, which occurs at approximately $10^{\circ} \mathrm{N}$, whereas near $120^{\circ} \mathrm{W}$ the SMC penetrates to $15^{\circ} \mathrm{S}$. Zhang et al. (2004) and Nolan, Zhang \& Chen (2007) attributed the cause of the SMC to SST gradients. In particular, Nolan et al. (2007) analyzed the SMC as a large-scale sea-breeze type circulation, driven by 
north-south SST gradients with shallow convection in the ITCZ region. They suggested that these SST gradients induce pressure gradients that produce the SMC; and find that a stronger SMC occurs when deep convection is absent in the ITCZ. Nolan, Powell, Zhang \& Mapes (2010) performed idealized simulations of the ITCZ and its multilevel flows. These multilevel flows include: Boundary Layer Inflow, Shallow Return Flow (SRF), Mid-level Inflow (MLI) and Upper-Level Outflow. In their study, the SRF is analyzed as a sea-breeze-like response to surface gradients of pressure and temperature, in particular, a strong meridional SST gradient near the equator. Their simulations show that both the SRF and MLI are robust features of the ITCZ in the eastern Pacific. Lindzen \& Nigam (1987) proposed this mechanism of surface temperature and pressure gradients to explain low-level wind in the trade cumulus boundary layer. They reported that SST and its gradients are correlated positively in the vertical through the depth of the trade cumulus layer. González \& Mora (2014) proposed the Ekman pumping off the top of the boundary layer as a possible mechanism for generating the SMC. The above authors developed a numerical model to simulate this mechanism, and successfully found this type of circulation when Ekman pumping was introduced in the model. From previous global analyses, it appears that shallow meridional circulations occur in several other parts of the globe. For example, Trenberth, Stepaniak \& Caron (2000) studied the mean annual cycle of the divergent wind and vertical motion using both the NCEP/ National Center for Atmospheric Research (NCAR) reanalysis and the ECMWF reanalysis. They applied a complex empirical orthogonal function (CEOF) analysis to the divergent wind, which produced two dominant modes of overturning throughout the tropical and subtropical troposphere. The first mode (CEOF1) is the deep overturning global monsoon mode in the troposphere, with a maximum in vertical motion at approximately $400 \mathrm{hPa}$, divergence in the upper troposphere (with a maximum at $150 \mathrm{hPa}$ ), and convergence in the lower troposphere with a maximum at $925 \mathrm{hPa}$ (ECMWF ERA-40) or $850 \mathrm{hPa}$ (NCEP/NCAR). The Hadley circulation, the Pacific and Atlantic Walker cells, and the Asia-Africa transverse cell are part of this deep overturning mode.

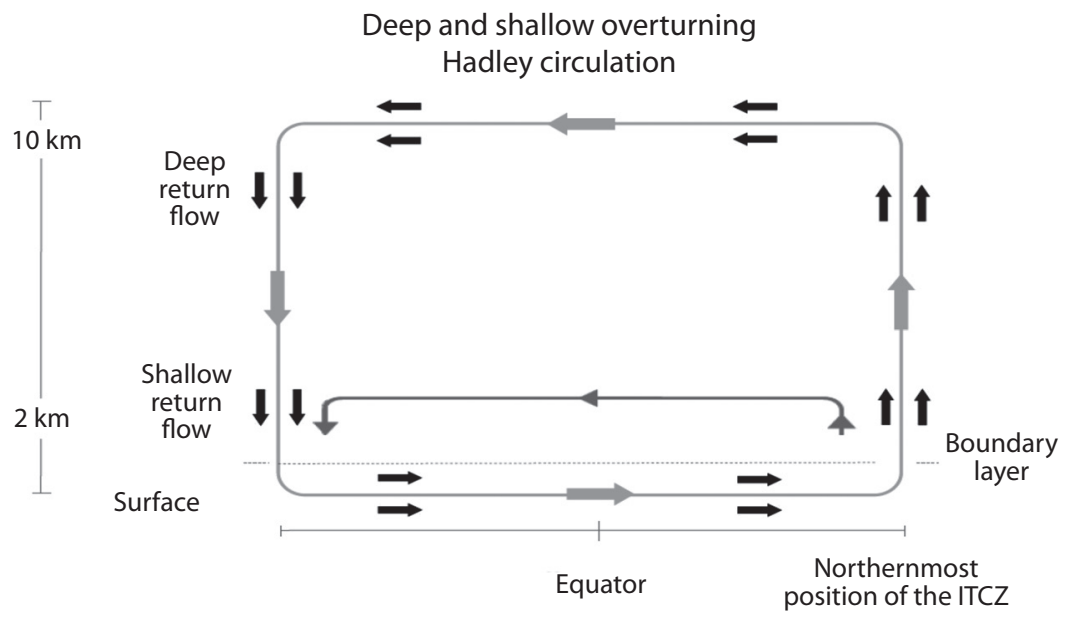

Fig. S1. A schematic view of the deep and shallow overturning Hadley circulation. 


\section{Interannual variability of tropical cyclones}

The presence of the WHWP on both sides of Central America and Mexico, the interannual variability of the CLLJ (see Part II) and moisture transport by this circulation (DuránQuesada et al., 2010) may provide favorable conditions for tropical cyclone development. These factors make the IAS one of the most active regions in the world, as far as the generation of tropical cyclones is concerned. Figures 13 and 14 present the annual frequency of total named tropical storms (TS) from 1966 to 2014 for the ETP and CS, respectively. The major hurricanes are those whose intensity reached or surpassed category or status 3 . Note, the large interannual variability of TS in both basins. In the ETP (Fig. 13) the number of TS during the period 1966-2014 does not show

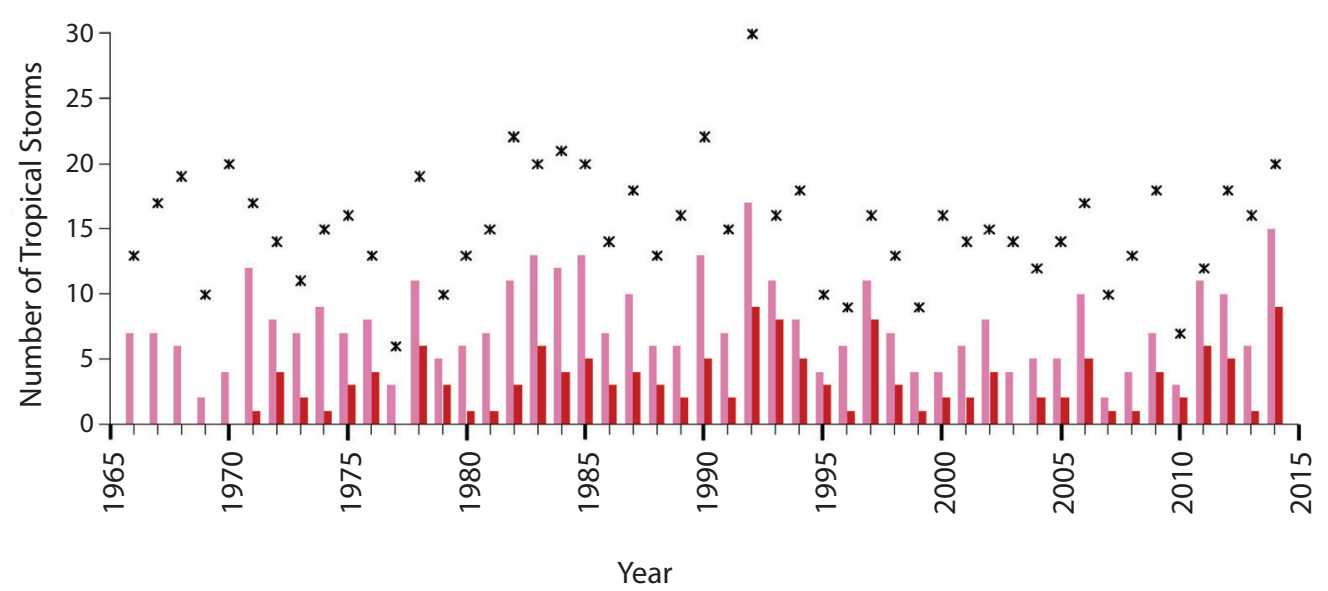

Fig. 13. Annual frequency of total named tropical storms (asterisks), hurricanes (pink), and major hurricanes (hurricane intensity reached or surpassed status 3, red) over the Eastern Tropical Pacific from 1966 to 2014. See Table 1 for details on data and data sources.

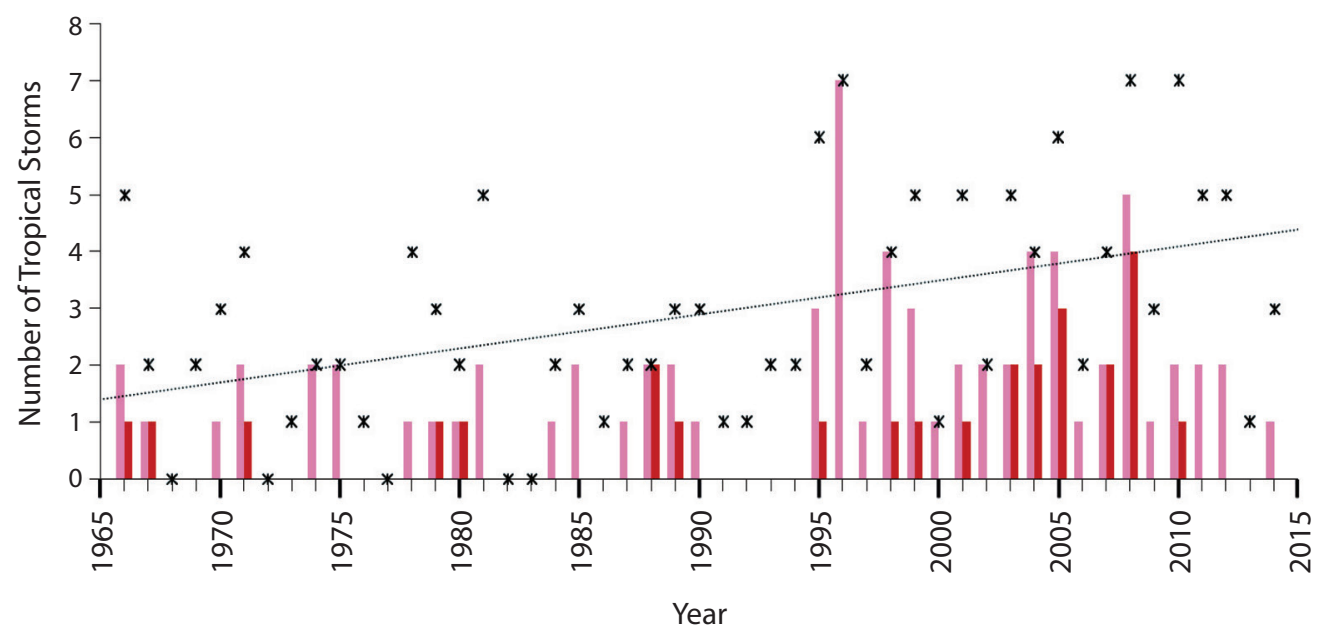

Fig. 14. Annual frequency of total named tropical storms (asterisks), hurricanes (pink), and major hurricanes (hurricane intensity reached or surpassed status 3, red) over the Caribbean Sea from 1966 to 2014. The dotted line is the linear trend of TS. See Table 1 for details on data and data sources. 
any significant trend, moreover, the number of major hurricanes decreased at the beginning of this century, whereas the 80's and 90's were very active. Only in the Caribbean (Fig. 14) the number of tropical storms shows a significant positive linear trend at the $99 \%$ confidence level, according to the Mann-Kendall test. Additionally, during that period, both hurricanes and major hurricanes also increased, except during the last four years of the record used. The above result of an increasing number of tropical storms over the CS, although not conclusive, is consistent with the findings of Giorgi (2006) about the region (Central America) being a hot-spot for climate change. However, if this region is a hot-spot, what makes the ETP different?

\section{Low frequency modes}

\subsection{El Niño-Southern Oscillation and the Pacific Decadal Oscillation}

ENSO has been identified as the most important mode of interannual climate variability in many regions across the globe. The warm phase of ENSO (El Niño) is characterized by anomalous warming of sea surface temperatures and negative anomalies of sea level pressure in the ETP region. Conversely, the cold phase of ENSO (La Niña) corresponds to widespread cooling of the Tropical Pacific (Cane, \& Zebiak, 1985; Trenberth, 1997; Wang, \& Fiedler, 2006). ENSO-related changes in surface pressure patterns lead to major changes in precipitation across the tropical Pacific.

In recent years, several studies have explored the relationship between ENSO and the climate of Central America and the ETP (Alfaro, 2014; Amador et al., 2006; Amador, 2008; Fallas-López, \& Alfaro, 2012a, 2012b; Fiedler, 2002; Quirós-Badilla, \& Alfaro, 2009). According to Amador, Magaña \& Pérez (2000), the intensity of CLLJ in the boreal summer increases (decreases) during warm (cold) ENSO events, and the opposite occurs during the boreal winter. For the month of July, Amador (2008) identified negative precipitation anomalies over the central Caribbean and the
Pacific slope of Central America when an El Niño event occurs. The Caribbean side of Central America, on the other hand, experienced positive precipitation anomalies possibly due to enhanced low-level moisture convergence offshore Nicaragua and Costa Rica associated with the large-scale jet dynamics. During La Niña, a weaker CLLJ in July leads to an anomalous reduction of the rainfall in the western Caribbean. Giannini, Kushnir \& Cane (2000) found differences in interannual variability of precipitation associated with ENSO in the Caribbean. In the case of the ETP, Quirós-Badilla \& Alfaro (2009) examined meteorological records from gauge stations at the Cocos Island and found that El Niño (La Niña) events are associated with positive (negative) precipitation and temperature anomalies over the island. The results of the statistical analyses performed by Fallas-López \& Alfaro (2012a; 2012b) indicate that above-normal (below-normal) precipitation accumulations during the August-October season in the Pacific slope of Central America are related to cold (warm) ENSO episodes and warm (cold) Atlantic temperatures. In addition, the rainy season in the region presents an early (late) end during El Niño (La Niña). The intensity, duration and the start-end dates of the mid-summer drought (MSD, Magaña, Amador, \& Medina, 1999) in Central America also shows a dependence on ENSO. The work of Alfaro (2014), for instance, shows that the MSD in two basins in the Pacific side of Costa Rica tend to be drier (wetter) during warm (cold) ENSO phases.

Very few studies have been reported on ENSO impacts on the marine biodiversity in the vicinity of Cocos Island. According to White, Myers, Mills, Fleming \& Baum (2015), although fishing pressure has increased the extinction risk of many elasmobranch (shark and ray) species, relative abundance of each species was highly influenced by ENSO activity, seasonality, and water temperature. The seasonal and monthly behavior of several ocean and near surface atmospheric parameters are treated in Part II of this study. 
Tropical cyclone activity in the Caribbean Sea is also modulated by ENSO. Amador, Alfaro, Rivera \& Calderón (2010) found that stronger (weaker) CLLJ summer winds associated with El Niño (La Niña) events lead to increased (decreased) low-level vertical wind shear in the Caribbean. These conditions inhibit (allow) deep convection and disfavor (favor) the development of tropical cyclones. Other studies that also analyzed the interannual variability of the cyclone-genetic activity in the tropical Atlantic are Chen \& Taylor (2002) and, Bell \& Chelliah (2006). Focusing on the ETP, Martínez-Sánchez \& Cavazos (2014) determined that the average frequency of categories 1-5 hurricanes during the peak tropical cyclone season (JulySeptember) is higher in neutral ENSO periods, followed by El Niño and La Niña years. In the case of the frequency of major (category 4-5) hurricanes, the authors showed that it is similar during El Niño and neutral years, and notably lower during La Niña.

Based on the work of Mantua et al. (1997) and Christensen et al. (2013), the PDO can be defined as the leading mode of decadal to multi-decadal variability in the North Pacific SST. This ENSO-like spatial pattern extends to the South Pacific and to the Indian and Atlantic Oceans. In the latter regions the PDO is less intense. The ENSO-PDO relationship (Zhang, Wallace, \& Battisti, 1997) and influence on patterns of precipitation, temperature and tropical cyclone activity has been investigated in some detail in the last decade (e.g., Chen, Feng, \& Wu, 2013; Hu, \& Huang, 2009; Martínez-Sánchez, \& Cavazos, 2014; Pavia, Graef, \& Reyes, 2006). Pavia et al. (2006) studied the role of the PDO in ENSO-associated climate anomalies in Mexico. They found that for precipitation, warm ENSO episodes are related to wet conditions during summers of cold PDOs and during winters of warm PDOs. However, with the exception of two warm ENSO-PDO cases, they indicated that no general pattern of constructive interference (i.e., El Niño and warm PDO or, La Niña and cold PDO) was found. Contrary to this finding, Hu \& Huang (2009) reported that climate anomalies in the United States Great
Plains are intensified when ENSO and PDO are in phase. When these two signals are out of phase, anomalies in that region tend to be neutral. An important practical result of the latter work is that without ENSO, PDO alone does not influence North American climate significantly. Martínez-Sánchez \& Cavazos (2014) determined a positive relationship between the frequency of intense (categories 4 and 5) tropical cyclones in the eastern tropical Pacific and PDO and ENSO warm and cold events. This is possibly due to an extension of the Pacific portion of the WHWP and reduced wind shear in the region of cyclogenesis. The above results clearly indicate that the effects of ENSO and/ or PDO on climate vary in many different ways depending on the modulation of regional systems by SST patterns.

Using combinations of several oceanic and atmospheric indices, Fallas-López \& Alfaro (2012a) found that a normalized PDO-Niño3 index is useful for the prediction of early or late onsets of the rainy season in Central America, while AMO + (PDO-Niño3) is one of the most skillful predictors for the intensity of the MSD, the August-September-October (ASO) precipitation maximum, and the end of the rainy season. The dependence of the ASO precipitation in Central America on the phase of the PDO was also examined by Maldonado, Alfaro, Fallas \& Alvarado (2013). In addition, Méndez \& Magaña (2010) found a relationship between PDO, AMO and prolonged droughts in Mexico. The authors argue that during negative phases of the PDO, the CLLJ weakens and transient activity increases. This leads to enhanced convection in southern Mexico and Central America and drought conditions over northern Mexico due to a reduction of moisture transport into the region.

Figure $15 \mathrm{~A}$ presents the time distribution of TS (annual anomaly from the median) in the entire ETP basin (bars), the MEI averaged from April-May to November-December (red line), and annual mean PDO index (blue line) from 1966 to 2014. As can be observed in this figure the PDO is an ENSO-like atmospheric signal. Except for a few years, TS positive (negative) 

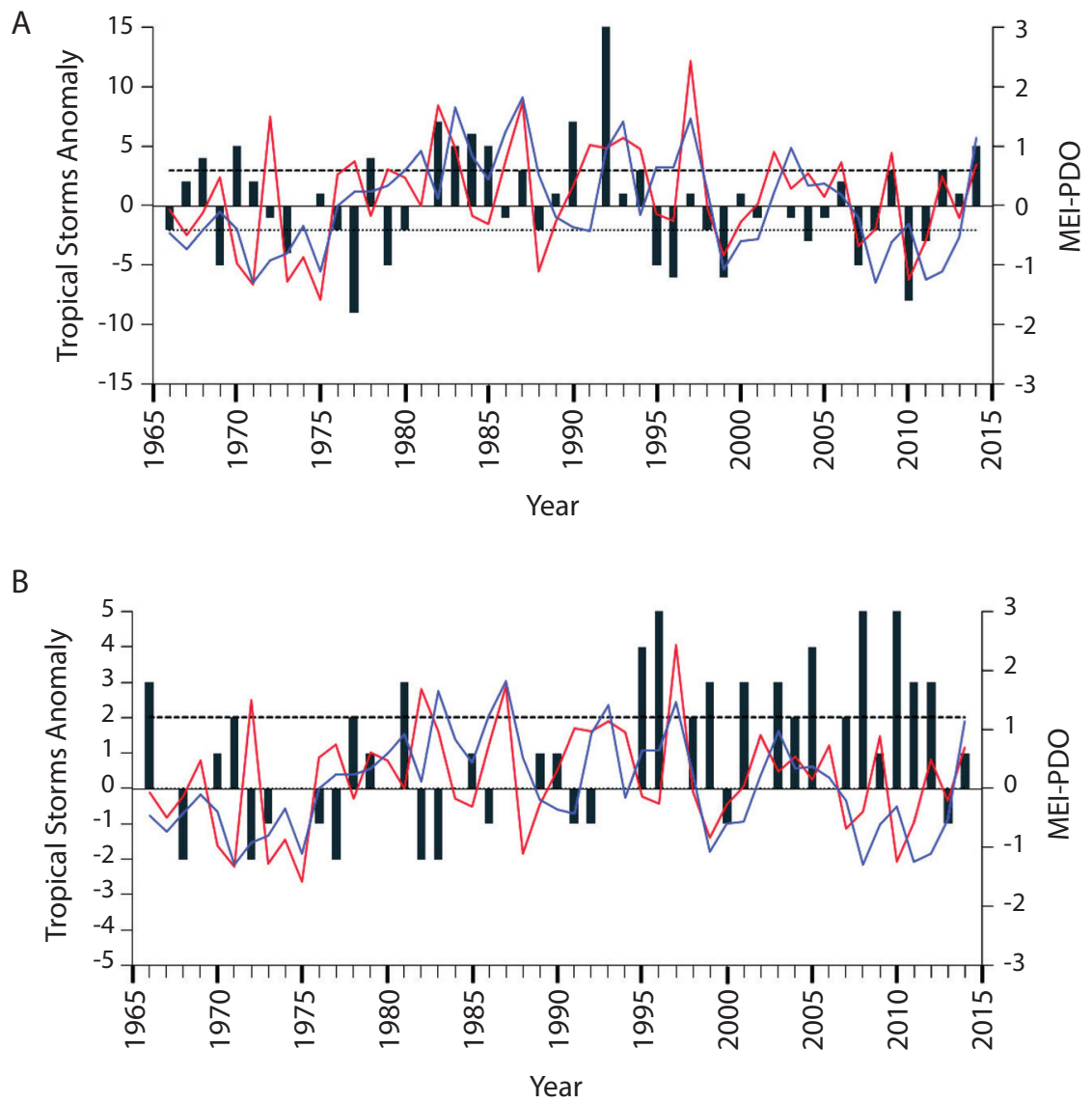

Fig. 15. Number of tropical cyclones (median anomaly) in the entire a) Eastern Tropical Pacific basin (bars), multivariate ENSO index averaged from April-May to November-December (red line), and annual mean PDO index (blue line) from 1966 to 2014. Short (long) dashed lines indicate the lower (upper) quartile of the tropical cyclone time series, and b) as in a) except for the Caribbean Sea $\left(10.0^{\circ} \mathrm{N}-22.5^{\circ} \mathrm{N} ; 60.0^{\circ} \mathrm{W}-82.5^{\circ} \mathrm{W}\right)$.

anomalies correspond with positive (negative) values of both indexes. Over the ETP, almost $56 \%$ of TS were present during the positive phase of MEI. For the Caribbean the relationship between TS and MEI/PDO is inversed (Fig. 15B). A $44 \%$ of TS were present during the MEI positive phases over the CS. The vertical wind shear over this region increases due to an increment of the mean wind field associated with the CLLJ, an element unfavorable for tropical cyclone generation (Amador et al., 2000; Amador, 2008). The results of this study extend the findings of Martínez-Sánchez \& Cavazos (2014) to TS, in which the major number of intense (categories 4 and 5) TS correlates positively with the warm phases of ENSO and the PDO. It also confirms the importance of SST positive anomalies (warm phases of both, ENSO and PDO) in the generation of TS. During PDO positive phases $52 \%$ of TS were present over the ETP, while for the CS, $49 \%$ of TS were present the PDO positive phase. Note that the area of the ETP is greater than that of the Caribbean, so the number of annual TS is expected to be larger in the ETP.

\subsection{Atlantic Multi-decadal Oscillation}

The AMO is a mode of variability imprinting its effect in the North Atlantic Ocean SST (Schlesinger, \& Ramankutty, 1994; Trenberth, 
$\&$ Shea, 2006). With a period of about $60-80$ years, the AMO is a coherent pattern in the entire North Atlantic basin. As discussed by Chylek, Klett, Lesins, Dubey \& Hengartner (2014), the AMO's origin is not yet fully understood. Some attribute its origin to natural variability (e.g., Zhang et al., 2013), others, following Chylek et al. (2014) and references therein, to anthropogenic aerosol radiative forcing. The AMO signal has been found to be linked to precipitation variability in regions such as Africa (Fontaine, \& Janicot, 1996), Europe (Rodwell, Rodwell, \& Folland, 1999), the Caribbean (Giannini, Saravana, \& Chang, 2003) and South America (Carton, Cao, Giese, $\&$ da Silva, 1996). Within the IAS, a positive phase of the AMO was reported to be related to a decrease in the moisture transport from the Gulf of Mexico to northwestern Mexico by Curtis \& Gamble (2008). The authors suggest that this decrease may be associated with a reduction in observed precipitation. Results by Zhang \& Delworth (2006) showed wetter (drier) conditions over Central America (northeast Brazil) during June-July-August (December-January-February) for positive AMO. Some studies suggest that the AMO is of importance to modulate the impact of ENSO on drought. Furthermore, Wang, Lee \& Enfield (2008) show that warm (cool) phases of the AMO are associated with repeatedly large (small) Atlantic warm pools. Those results may suggest a relationship between the AMO and Atlantic tropical cyclones. This is in agreement with results that report multidecadal variations in hurricane activity due to the Atlantic SST (e.g., Landsea, Pielke, Mestas-Núñez, \& Knaff, 1999; Goldenberg, Landsea, Mestas-Núñez, \& Gray, 2001).

Time series of annual TS frequencies are shown in Figs. 16A, B, as in Figs. 15A and $15 \mathrm{~B}$, but along with the AMO rather than MEI/ PDO. In the period used here (1966-2014) there is barely one AMO oscillation, so this makes difficult to arrive at any solid conclusion. However, by looking at both AMO phases, the dispersion pattern of variables suggests no relationship between them during this period. Note that the sign of the TS anomaly with respect to any AMO phase is not consistent as is the case discussed above between PDO, ENSO and TS. A $61 \%$ of tropical cyclones over the Caribbean were in the positive phase of AMO, the rest were in the negative phase. For the ETP, $41 \%$ of TS were in the AMO positive phase. This is consistent with the findings of Klotzbach \& Gray (2008).

\section{Summary and conclusions}

The ETP is influenced by a variety of atmospheric and oceanic systems and processes. It has been the study area of many international experiments and scientific campaigns. Detailed analyses of the annual cycle of the lower atmosphere and the underlying ocean in the tropics was carried out by Wyrtki (1965a, 1965b, 1966, 1967), Taylor (1973), Wyrtki \& Meyers (1975a, 1975b), Hastenrath \& Lamb (1978), Horel (1982), Sadler et al. (1987a, 1987b) and Hastenrath (1991), for the ETP.

Among the international experiments, the Climate Experiment over the Americas Warm Pools (ECAC in Spanish) aimed at improving the understanding of the elements controlling climate in Mexico, Central America, and the Caribbean, was conducted in 2001. Observations were made in regions with meager information (e.g., ETP and near the CLLJ) or where no atmospheric data had been collected before. ECAC objectives were to document the atmospheric and oceanic processes related to the MSD over the Northeast Pacific warm pool, and the CS; to examine the air-sea interaction processes over these warm pools that modulate the intensity and distribution of the rainy season on a regional basis, and to make in situ sounding observations of the CLLJ during summer over selected regions of the Caribbean. Amador (2008) reported some of the findings of ECAC.

About the same time, an initiative of the IAI (IAI-CRN062) provided the opportunity to update the knowledge about some atmospheric and oceanic processes in the ETP (e.g., Amador et al., 2006). This work (Part I) and a companion 


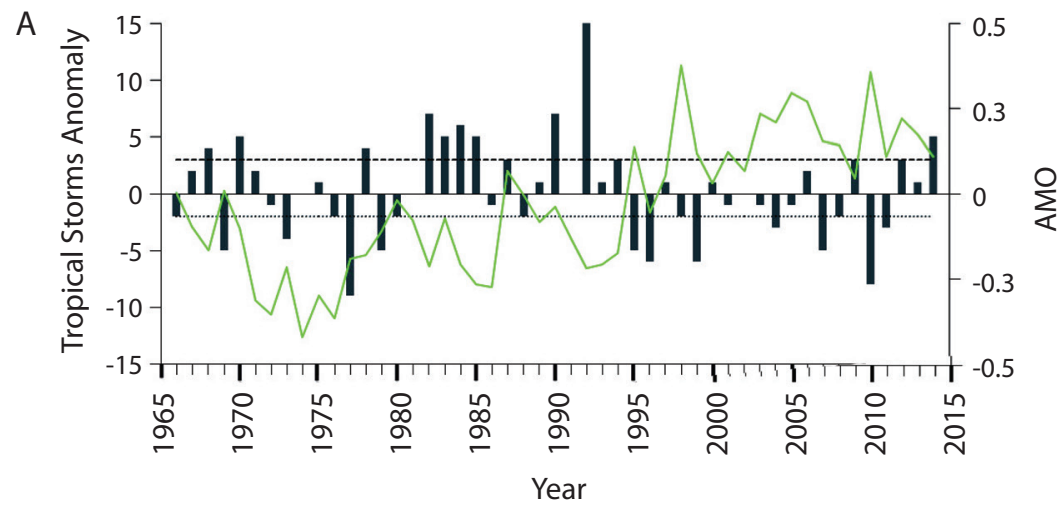

B

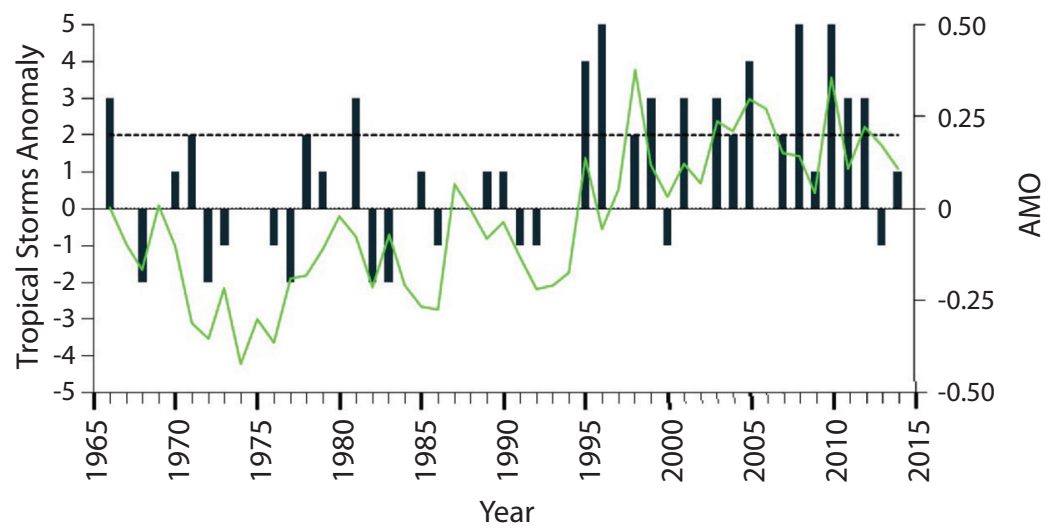

Fig. 16. Number of tropical cyclones (median anomaly) in the entire a) Eastern Tropical Pacific basin (bars), and annual mean AMO index (green line) from 1966 to 2014. Short (long) dashed lines indicate the lower (upper) quartile of the tropical cyclone time series, b) as in a) except for the Caribbean Sea $\left(10.0^{\circ} \mathrm{N}-22.5^{\circ} \mathrm{N} ; 60.0^{\circ} \mathrm{W}-82.5^{\circ} \mathrm{W}\right)$.

paper (Part II) are dedicated to a climate, and a climate variability review, respectively, of ETP main low-level atmospheric and near surface oceanic structure. Both studies are part of a CONARE project on "Parque Nacional Isla del Coco y Aguas Adyacentes". Details of data and data sources are in Table 1. Annual values of solar radiation, surface energy fluxes, SST, sea level pressure, salinity, $10 \mathrm{~m}$ height wind fields, the wind stress curl, mean precipitation and evaporation were updated nearly until 2012, to extend the work of Amador et al. (2006). Low atmospheric frequency modes affecting the ETP, such as, ENSO, the PDO, and AMO were also briefly discussed. A Sidebar dealing with the shallow meridional circulation in the Hadley cell was included, since this feature is barely known by tropical oceanographers in the region. Besides that, its interactions with other seasonal and intraseasonal modes has not been fully studied, so, it is a characteristic of the ETP open for future research. As discussed before, past research has linked this feature with the SST gradients in the ETP.

In general, mean fields of variables mentioned above are in good agreement with the work of Amador et al. (2006), among others. The results shown here have the advantage, over the study just mentioned, that the resolution of the fields provide much more detail of the mesoscale character of the variables over the ETP (for example, see Fig. 10, and Fig. 6 of Amador et al., 2006). For other variables, such as the heat fluxes and evaporation the 
above statement is also valid. This is believed to supply high quality data and basic data analysis for researches dealing with marine processes in tropical regions, especially in the ETP. Also, this study is expected to serve as a basic reference for other authors doing oceanic research in the region. Regarding tropical cyclone activity, the number of TS in the ETP does not show any significant trend during the period 1966-2014; additionally, the number of major hurricanes decreased at the beginning of this century, whereas the 80 's and 90's were very active. In the Caribbean, the number of TS showed a significant positive trend. In this basin, both hurricanes and major hurricanes increased, except during the last four years of the record used. TS anomalies in the ETP and the PDO-ENSO temporal index distribution are positively correlated. This result extends the findings of Martínez-Sánchez \& Cavazos (2014). For the Caribbean basin the correlation is negative. No relationship between AMO and TS anomalies in the ETP was found. In the Caribbean, on the other hand, the number of tropical cyclones is greater in the positive phase of AMO than that for the negative phase. This is consistent with the results of Klotzbach \& Gray (2008).

In regard to impacts of low-frequency modes on the ETP and CS marine biodiversity, very few studies have been reported so far. A recent work by White et al. (2015), found an interest relationship between some species of sharks and rays and the ENSO mode. For one of these species, marble ray relative abundance decreased with increasing El Niño activity and water temperature, but it was positively associated with stronger currents, greater visibility, and the wet season (June to November). As shown by Amador et al. (2006), there is a break in the wet season in the region, the MSD. This characteristic of the annual cycle of precipitation also affects the region of the Cocos Island, during July-August. Does the above statement of White et al. (2015) hold also for the MSD? What is the relationship between the MSD, low-frequency atmospheric modes and changes in the above species? Or in other species?
This study provides useful data and data analysis over the ETP and Caribbean basin at a better resolution than that of Amador et al. (2006). However, some of the features over these two regions are still far from being understood. Such is the case of the shallow meridional circulation in the Hadley cell, and the transport of properties of the CLLJ from the Caribbean into the ETP. Large and medium scale resolution modelling $(50 \mathrm{Km}$ and $10 \mathrm{Km}$, respectively) in this part of the tropics should provide more insight into the mechanisms acting on the observed complex interaction of ocean-atmosphere processes.

\section{ACKNOWLEDGMENTS}

The authors wish to acknowledge the support of the following projects: IAI-CRN2-050, UCR-VI-805-B0-065, A8-606, B0-130, A9-224, A7-002, B0-402, B3-600, B4-227 and 808-A9-180, and show their appreciation to four anonymous reviewers for helpful comments and suggestions. J.A.A. thanks Dr. Jorge Cortés, P.I. of the project "CONARE: Interacciones océano-atmósfera y la biodiversidad marina de la Isla del Coco, Costa Rica", for the opportunity to collaborate in this research. Thanks also to Ingrid Rivera, Carla Vega, Carlos Bojorge, Paula Pérez and Xiannie Rivas for their extensive collaboration in the logistics of data and the elaboration of some of the figures for this paper. A.M.D.Q acknowledges Daiana García and Pedro Chaves for data retrieval during complimentary scholar assistantship service.

\section{RESUMEN}

La parte oriental del Pacífico tropical. Parte I: Una revisión del clima. El Pacífico Tropical del Este (PTE) está caracterizado por una gran variedad de sistemas atmosféricos y oceánicos, que actúan en un dominio de interacciones de multi-escala. Esta es la Parte I de un estudio de revisión en dos partes acerca del clima y la variabilidad climática del PTE. Los campos medios de radiación solar, flujos de energía superficiales, temperatura de la superficie del mar, presión a nivel del mar, salinidad, vientos a $10 \mathrm{~m}$ de altura, el rotor del esfuerzo del viento, 
precipitación y evaporación son actualizados con los datos disponibles, incluidos los de la última década. Dada la fuerte interacción entre el PTE y el Mar Caribe-Océano Atlántico, las discusiones sobre los campos medios se presentan para dos dominios diferentes; uno relativamente grande que va desde $24^{\circ} \mathrm{S}-36^{\circ} \mathrm{N}$ y de $129^{\circ} \mathrm{W}$.- $17^{\circ} \mathrm{W}$ y otro más pequeño que comprende el Mar Caribe y la región más oriental del PTE. La mayor parte de los resultados generados del clima, pueden ser usados como línea base para estudios de cambio climático regional. Para las dos cuencas en el dominio más pequeño, se muestra también la variabilidad interanual de ciclones tropicales. El estudio se complementa con una corta revisión de modos de baja frecuencia, tales como El Niño-Oscilación del Sur, la Oscilación Decenal del Pacífico y la Oscilación Multi-Decenal del Atlántico. Se conoce, que estos modos de baja frecuencia, modulan de alguna manera los sistemas en esta región, incluida la frecuencia de ciclones tropicales.

Palabras clave: Isla del Coco, Oriente del Pacífico Tropical, Mar Caribe, clima, ciclones tropicales, modos de baja frecuencia, circulación meridional de bajo nivel.

\section{REFERENCES}

Adler, R. F., Huffman, G. J., Chang, A., Ferraro, R., Xie, P., Janowiak, J., ... Nelkin, E. (2003). The Version-2 Global Precipitation Climatology Project (GPCP) Monthly Precipitation Analysis (1979-Present). Journal of Hydrometeorology, 4, 1147-1167.

Alfaro, E. (2014). Caracterización del "veranillo" en dos cuencas de la vertiente del Pacífico de Costa Rica, América Central. Revista de Biología Tropical, 62(Supplement 4), 1-15.

Alfaro, E. J. \& Cortés, J. (2012). Atmospheric forcing of cold subsurface water events in Bahía Culebra, Costa Rica. Revista de Biología Tropical, 60(Supplement 2), 173-186.

Allen, G. R. (2008). Conservation hotspots of biodiversity and endemism for Indo-Pacific coral reef fishes. Aquatic Conservation: Marine and Freshwater Ecosystems, 118, 541-556.

Amador, J. A. (1998). A climatic feature of tropical Americas: The trade wind easterly jet. Tópicos Meteorológicos y Oceanográficos, 5(2), 91-102.

Amador, J. A. (2008). The Intra-Americas Sea Low-level Jet, overview and future research. Annals of the New York Academy of Science, 1146, 153-188. doi: 10.1196/annals.1446.012

Amador, J. A., Magaña, V. O., \& Pérez, J. B. (2000). The low level jet and convective activity in the Caribbean. Preprints 24th Conference on Hurricanes and Tropical Meteorology (pp.114-115). Fort Lauderdale, FL: American Meteorological Society.
Amador, J. A., Alfaro, E., Lizano, O., \& Magaña, V. (2006). Atmospheric forcing in the Eastern Tropical Pacific: A review. Progress in Oceanography, 69, 101-142.

Amador, J. A., Alfaro, E., Rivera, E., \& Calderón, B. (2010). Climatic features and their relationship with Tropical Cyclones over the Intra-Americas Seas. Hurricanes and Climate Change, 2, 149-173. doi: 10.1007/978-90-481-9510-79.

Amador, J. A., Durán-Quesada, A. M., Rivera, E. R., Mora, G., Sáenz, F., Calderón, B., \& Mora, N. (2015). The easternmost tropical Pacific. Part II: Seasonal and intraseasonal modes of atmospheric variability. Revista de Biología Tropical, 64(Supplement 1), S23-S57.

Atlas, R., Hoffman, R. N., Ardizzone, J., Leidner, S. M., Jusem, J. C., Smith, D. K., Gombos, D. (2011). A cross-calibrated, multiplatform ocean surface wind velocity product for meteorological and oceanographic applications. Bulletin of the American Meteorological Society, 92, 157-174.

Bell, G. D., \& Chelliah, M. (2006). Leading Tropical Modes Associated with Interannual and Multidecadal Fluctuations in North Atlantic Hurricane Activity. Journal of Climate, 19, 590-612. doi: http://dx.doi. org/10.1175/JCLI3659.1

Cane, M. A., \& Zebiak, S. E. (1985). A theory for El Niño and the Southern Oscillation. Science, 228(4703), 1085-1087.

Carton J. A., \& Giese, B. S. (2008). A Reanalysis of Ocean Climate Using Simple Ocean Data Assimilation (SODA). Monthly Weather Review, 136, 2999-3017.

Carton, J. A., Cao, X., Giese, B. S., \& da Silva, A. M. (1996). Decadal and interannual SST variability in the tropical Atlantic Ocean. Journal of Physical Oceanography, 26, 1165-1175.

Chelton, D. B., Esbensen, S. K., Schlax, M. G., Thum, N., Freilich, M. H., Wentzand, F. J., ... Schopf, P. S. (2001). Observations of coupling between surface wind stress and sea surface temperature in the eastern tropical Pacific. Journal of Climate, 14, 1479-1498.

Chen A. A., \& Taylor, M. A. (2002). Investigating the link between early season Caribbean rainfall and the El Niño +1 year. International Journal of Climatology, 22, 87-106.

Chen, W., Feng, J., \& Wu, R. (2013). Roles of ENSO and PDO in the Link of the East Asian Winter Monsoon to the following Summer Monsoon. Journal of Climate, 26, 622-635. doi: http://dx.doi.org/10.1175/ JCLI-D-12-00021.1

Christensen, J. H., Kumar, K., Aldrian, E., An, S. I., Cavalcanti, I. F. A., de Castro, ... Zhou, V. (2013). Climate phenomena and their relevance for future regional climate change. In T. F. Stocker et al. (Eds.), Climate Change 2013: The physical science 
basis. contribution of working group I to the fifth assessment report of the intergovernmental panel on Climate Change (pp. 1217-1308). Stockholm, Sweden: Cambridge University Press.

Chylek, P., Klett, J. D., Lesins, G., Dubey, M. K., \& Hengartner, N. (2014). The Atlantic Multidecadal Oscillation as a dominant factor of oceanic influence on climate. Geophysical Research Letters, 41, 16891697. doi: 10.1002/2014GL059274

Cook, K. H., \& Vizy E. K. (2010). Hydrodynamics of the Caribbean low-level jet and its relationship to precipitation. Journal of Climate, 23(6), 1477-1494.

Curtis, S., \& Gamble, D. W. (2008). Regional variations of the Caribbean Mid-Summer Drought. Theoretical and Applied Climatolology, 94, 25-34. doi: 10.1007/ s00704-007-0342-0

da Silva, A., Young, A. C., \& Levitus, S. (1994). Algorithms and Procedures. NOAA Atlas of Surface Marine Data, 1. Atlas NESDIS 6. Washington, DC: US Department of Commerce.

Dee, D. P., Uppala, S. M., Simmons, A. J., Berrisford, P., Poli, P., Kobayashi, S., ... Vitart, F. (2011). The ERAInterim reanalysis: configuration and performance of the data assimilation system. Quarterly Journal of the Royal Meteorological Society, 137, 553-597. doi: 10.1002/qj.828

Durán-Quesada, A. M., Gimeno, L., Amador, J. A., \& Nieto, R. (2010). Moisture sources for Central America: Identification of moisture sources using a Lagrangian analysis technique. Journal of Geophysical Research, 115(D05103). doi: 10.1029/2009JD012455

Enfield, D. B., Mestas-Núñez, A. M. \& Trimble, P. J. (2001). The Atlantic Multidecadal Oscillation and its relationship to rainfall and river flows in the continental U.S. Geophysical Research Letters, 28, 2077-2080.

Fallas-López B., \& Alfaro, E. (2012a). Uso de herramientas estadísticas para la predicción estacional del campo de precipitación en América Central como apoyo a los Foros Climáticos Regionales. 1: Análisis de tablas de contingencia. Revista de Climatología, 12, 61-79.

Fallas-López B., \& Alfaro, E. (2012b). Uso de herramientas estadísticas para la predicción estacional del campo de precipitación en América Central como apoyo a los Foros Climáticos Regionales. 1: Análisis de correlación canónica. Revista de Climatología, 12, 93-105.

Fiedler, P. C. (2002). Environmental change in the eastern tropical Pacific Ocean: review of ENSO and decadal variability. Marine Ecology Progress Series, 244, 265-283.

Fontaine, B., \& Janicot, S. (1996). Sea surface temperature fields associated with West African rainfall anomaly types. Journal of Climate, 9, 2935-2940.
Giannini, A., Kushnir, Y., \& Cane, M. A. (2000). Interannual variability of Caribbean rainfall, ENSO, and the Atlantic Ocean. Journal of Climate, 13(2), 297-311.

Giannini, A., Saravana R., \& Chang, P. (2003). Oceanic forcing of Sahel rainfall on interannual to interdecadal time scales. Science, 302, 1027-1030. doi: 10.1126/science. 1089357

Giorgi, F. (2006). Climate change hot-spots. Geophysics Research Letters, 33, 8707.

Goldenberg, S., Landsea, C., Mestas-Núñez, A., \& Gray, W. (2001). The recent increase in Atlantic hurricane activity: Causes and Implications. Science, 293, 474-479.

González, A., \& Mora, G. (2014). Balanced dynamics of the deep and shallow Hadley circulations in the tropics. Journal of Advances Modeling Earth Systems, 6. doi: 10.1002/2013MS000278

Guzmán, H. M., \& Cortés, J. (1992). Cocos Island (Pacific of Costa Rica) coral reefs after the 1982-83 El Niño disturbance. Revista Biología Tropical, 40(3), 309-324.

Guzmán, H. M., \& Cortés, J. (2001). Changes in reef community structure after fifteen years of natural disturbances in the eastern Pacific (Costa Rica). Bulletin of Marine Science, 69(1), 133-149.

Hastenrath, S. (1991). Climate Dynamics of the Tropics. Dordrecht: Kluwer Academic Publishers.

Hastenrath, S., \& Lamb, P. J. (1978). On the dynamics and climatology of surface flow over the equatorial oceans. Tellus, 30, 436-448.

Holton, J. R. (2004). An Introduction to Dynamic Meteorology (2nd Ed.). New York, NY: Academic Press.

Horel, J. D. (1982). On the Annual cycle of the Tropical Pacific Atmosphere and Ocean. Monthly Weather Review, 110, 1863-1878.

Hu, Z-Z., \& Huang, B. (2009). Interferential impact of ENSO and PDO on dry and wet conditions in the U.S. Great Plains. Journal of Climate, 22, 6047-6065. doi: http://dx.doi.org/10.1175/2009JCLI2798.1

Huffman, G. J., Adler, R. F., Bolvin, D. T., Gu, G. J., Nelkin, E. J., Bowman, K. P., ... Wolff, D. B. (2007). The TRMM multisatellite precipitation analysis (TMPA): Quasi-global, multiyear, combined-sensor precipitation estimates at fine scales. Journal of Hydrometeorology, 8, 38-55.

Klotzbach, P. J., \& Gray, W. M. (2008). Multidecadal variability in North Atlantic Tropical cyclone activity. Journal of Climate, 21, 3929-3935. doi: http://dx.doi. org/10.1175/2008JCLI2162.1

Lagerloef, G., Wentz, F., Yueh, S., Kao, H. Y., Johnson, G. C., \& Lyman, J. M. (2012). Aquarius satellite mission provides new, detailed view of sea surface 
salinity. Bulletin American Meteorological Society, 93(7), 70-71.

Landsea, C. W., Pielke, Jr. R. A., Mestas-Núñez, A. M., \& Knaff, J. A. (1999). Atlantic basin hurricanes: Indices of climatic changes. Climatic Change, 42, 89-129.

Lindzen, R., \& Nigam, S. (1987). On the role of sea surface temperature gradients in forcing low-level winds and convergence in the tropics. Journal of Atmospheric Sciences, 44, 2418-2436.

Magaña, V. O., Amador, J. A., \& Medina, S. (1999). The mid-summer drought over Mexico and Central America. Journal of Climate, 12, 1577-1588.

Maldonado, T., Alfaro, E., Fallas, B., \& Alvarado, L. (2013). Seasonal prediction of extreme precipitation events and frequency of rainy days over Costa Rica, Central America, using Canonical Correlation Analysis. Advances in Geosciences, 33, 41-52.

Mantua, N. J., Hare, S. R., Zhang, Y., Wallace, J. M., \& Francis, R. C. (1997). A Pacific interdecadal climate oscillation with impacts on salmon production. Bulletin of the American Meteorological Society, 78, 1069-1079.

Martínez-Sánchez, J. N., \& Cavazos, T. (2014). Eastern Tropical Pacific hurricane variability and landfalls on Mexican coasts. Climate Research, 58, 221-234.

Méndez, M., \& Magaña, V. (2010). Regional aspects of prolonged meteorological droughts over Mexico and Central America. Journal of Climate, 23, 1175-1188. doi: http://dx.doi.org/10.1175/2009JCLI3080.1

Neiburger, M., Johnson, D., \& Chien, C. (1961). Studies of the structure of the atmosphere over the Eastern Pacific Ocean in summer, I. The inversion over the eastern North Pacific Ocean. University of California Publications in Meteorology, 1, 1-94.

Nolan, D., Zhang, C., \& Chen, S. (2007). Dynamics of the shallow meridional circulation around Intertropical Convergence Zones. Journal of Atmospheric Sciences, 64, 2262-2285.

Nolan, D., Powell, S., Zhang, C., \& Mapes, B. (2010). Idealized simulations of the Intertropical Convergence Zone and its multilevel flows. Journal of Atmospheric Sciences, 67, 4028-4053.

Pavia, E. G., Graef, F., \& Reyes, J. (2006). PDO-ENSO Effects in the climate of Mexico. Journal of Climate, 19, 6433-6438. doi: http://dx.doi.org/10.1175/ JCLI4045.1

Poveda, G., \& Mesa, O. J. (2000). On the existence of Lloró (the rainiest locality on Earth): Enhanced ocean-land-atmosphere interaction by a low-level jet. Geophysical Research Letters, 27, 1675-1678.

Quirós-Badilla, E. \& Alfaro, E. (2009). Algunos aspectos relacionados con la variabilidad climática en la Isla del Coco, Costa Rica. Revista de Climatología, 9, $33-44$.
Reyes, S., \& Vogel, G. (1981). Meteorological and climatological observations on Coco Island. Observaciones meteorológicas y climatológicas en la Isla del Coco. Revista Geofísica, (14/15), 85-93.

Reynolds, R. W., Rayner, N. A., Smith, T. M., Stokes, D. C., \& Wang, W. (2002). An improved in situand satellite SST analysis for climate. Journal of Climate, 15, 1609-1625.

Reynolds, R. W., Smith, T. M., Liu, C., Dudley, B., Chelton, Casey, K. S., \& Schlax, M. G. (2007). Daily High-Resolution-Blended analyses for sea surface temperature. Journal of Climate, 20, 5473-5496.

Rodwell, M. J., Rodwell, D. P., \& Folland, C. K. (1999). Oceanic forcing of the wintertime North Atlantic oscillation and European climate. Nature, 398, 320-323.

Sadler, J. C., Lander, M. A., Hori, A. M., \& Oda, L. K. (1987a). Tropical marine climatic atlas. Indian and Atlantic Oceans. (Report UHMET 87-01). Honolulu, Hawaii: Department of Meteorology, University of Hawaii.

Sadler, J. C., Lander, M. A., Hori, A. M., \& Oda, L. K. (1987b). Tropical marine climatic atlas. Pacific Ocean. (Report UHMET 87-02). Honolulu, Hawaii: Department of Meteorology, University of Hawaii.

Schlesinger, M. E., \& Ramankutty, N. (1994). An oscillation in the global climate system of period 65-70 years. Nature, 367(6465), 723-726. doi: 10.1038/367723a0

Taylor, R. C. (1973). An atlas of Pacific island rainfall. Hawaii Institute Geophysics, 25, HIG-73-9(25), 1-175 (NTIS N0AD 767073).

Trenberth, K. E. (1997). The definition of El Niño. Bulletin of the American Meteorological Society, 78, 2771-2777.

Trenberth, K. E., \& Shea, D. J. (2006). Atlantic hurricanes and natural variability in 2005. Geophysical Research Letters, 33, L12704. doi: 10.1029/2006GL026894

Trenberth, K., Stepaniak, D., \& Caron, J. (2000). The global monsoon as seen through the divergent atmospheric circulation. Journal of Climate, 13, 3969-3993.

Umatani, S., \& Yamagata, T. (1991). Response of the Eastern Tropical Pacific to meridional migration of the ITCZ: The generation of the Costa Rica Dome. Journal of Physical Oceanography, 21, 346-363.

Uppala, S. M., Kållberg, P. W., Simmons, A. J., Andrae, U., da Costa Bechtold, V., Fiorino, M., ... Woollen, J. (2005). The ERA-40 re-analysis. Quaterly Journal of the Royal Meteorological Society, 131, 2961-3012.

Von Ficker, H. (1936). Die Passatinversion. Veröoeff. Meteorological Institute University of Berlin, 1, 1-33.

Wang, C., \& Enfield, D. B. (2001). The tropical western hemisphere warm pool. Geophysical Research Letters, 28(8), 1635-1638. 
Wang, C., \& Enfield, D. B. (2003). A further study of the tropical western hemisphere warm pool. Journal of Climate, 16, 1476-1493.

Wang, C., \& Fiedler, P. (2006). ENSO variability in the eastern tropical Pacific: A review. Progress in Oceanography, 69(2-4), 239-266.

Wang, Y., Xie, S. P., Wang, B., \& Xu, H. (2005). Largescale atmospheric forcing by southeast Pacific boundary-layer clouds: A regional model study. Journal of Climate, 18, 934-951.

Wang, C., Lee, S. K., \& Enfield, D. B. (2008). Climate response to anomalously large and small Atlantic Warm Pools during the summer. Journal of Climate, 21, 2437.

White, E. R., Myers, M. C., Flemming, J. M., \& Baum, J. K. (2015). Shifting elasmobranch community assemblage at Cocos Island- an isolated marine protected area. Conservation Biology, 29, 1186-1197. doi:10.1111/cobi.12478

Whyte, F. S., Taylor, M. A., Stephenson, T. S., \& Campbell, J. D. (2008). Features of the Caribbean low level jet. International Journal of Climatology, 28(1), 119-128.

Wolter, K., \& Timlin, M. S. (1998). Measuring the strength of ENSO events - how does 1997/98 rank? Weather, 53, 315-324.

Wyrtki, K. (1965a). The annual and semiannual variation of SST in the North Pacific Ocean. Limnology and Oceanography, 10, 307-313.

Wyrtki, K. (1965b). The thermal structure of the eastern Pacific Ocean. Deutsche Hydrographische Zeitzung, A6, Erganzungsheft, 84.

Wyrtki, K. (1966). Oceanography of the eastern equatorial Pacific Ocean. Oceanography and Marine Biology. An Annual Review, 4, 33-68.

Wyrtki, K. (1967). Circulation and water masses in the eastern equatorial Pacific Ocean. International Journal of Oceanology and Limnology, 1(2), 117-147.

Wyrtki, K., \& Meyers, G. (1975a). The trade wind field over the Pacific Ocean Part I: The mean field and the mean annual variation. (Tech. Rept. HIG-75-1, 26, + 38 figs). Honolulu, Hawaii: University of Hawaii.

Wyrtki, K., \& Meyers, G. (1975b). The trade wind field over the Pacific Ocean Part II: Bimonthly fields of wind stress: 1950 to 1972. (Tech. Rept. HIG-75-2, 16, +132 figs). Honolulu, Hawaii: University of Hawaii.

Yu, L., Jin, X., \& Weller, R. A. (2007). Annual, seasonal, and interannual variability of air-sea heat fluxes in the Indian Ocean. Journal of Climate, Special issue on the Climate Variability and Predictability of the Indian Ocean, 20, 3190-3209.

Yu, L., Jin, X., \& Weller, R. A. (2008). Multidecade global flux datasets from the objectively analyzed air-sea fluxes (OAFlux) Project: Latent and sensible heat fluxes, ocean evaporation, and related surface meteorological variables. (OAFlux Project Technical Report. OA-2008-01, 64). Massachusetts, USA: Woods Hole Oceanographic Institution.

Zhang, C., McGauley, M., \& Bond, N. (2004). Shallow meridional circulation in the tropical eastern Pacific. Journal of Climate, 17, 133-139.

Zhang, R., \& Delworth, T. L. (2006). Impact of Atlantic multidecadal oscillations on India/Sahel rainfall and Atlantic hurricanes. Geophysical Research Letters, 33, L17712. doi: 10.1029/2006GL026267

Zhang, R., Delworth, T. L., Sutton, R., Hodson, D. L. R., Dixon, K. W., Held, I. M., ... Vecchi, G. A. (2013). Have aerosols caused the observed Atlantic multidecadal variability? Journal of Atmospheric Sciences, $70,1135-1144$

Zhang, Y., Wallace, J. M., \& Battisti, D. S. (1997). ENSOlike interdecadal variability: 1900-93. Journal of Climate, 10, 1004-1020.

Zhang, Y-C., Rossow, W. B., Lacis, A. A., Oinas, V., \& Mishchenko, M. I. (2004). Calculation of radiative fluxes from the surface to top of atmosphere based on ISCCP and other global data sets: Refinements of the radiative transfer model and the input data. Journal of Geophysical Research, 109, D19105. doi: 10.1029/2003JD004457 